\title{
Eutrophication of a Maryland/Virginia Coastal Lagoon: a Tipping Point, Ecosystem Changes, and Potential Causes
}

\author{
Patricia M. Glibert • Deborah C. Hinkle • Brian Sturgis • \\ Roman V. Jesien
}

Received: 14 October 2012 /Revised: 22 March 2013 / Accepted: 6 April 2013 /Published online: 30 April 2013

(C) The Author(s) 2013. This article is published with open access at Springerlink.com

\begin{abstract}
Water quality in the Maryland/Virginia Coastal Bays has been declining for many years from anthropogenic inputs, but conditions appear to have worsened abruptly following a shift from long-term dry to long-term wet conditions in the early 2000s. Annually and regionally averaged total nitrogen concentrations are approximately twofold higher, but ammonium $\left(\mathrm{NH}_{4}{ }^{+}\right)$concentrations are up to an order of magnitude higher than in the early 1990s. Averaged nitrate concentrations, however, changed to a lesser degree throughout the time course; water column concentrations remain very low. Total phosphorus has only increased in some bay segments, but increases in phosphate $\left(\mathrm{PO}_{4}{ }^{3-}\right)$ have been more pervasive. There were differences in the year in which large increases in each nutrient were first noted: $\mathrm{PO}_{4}{ }^{3-}$ in $\sim 2001-2002$, followed by $\mathrm{NH}_{4}{ }^{+} \sim$ a year later. The effects of a combination of steadily increasing anthropogenic nutrient increases from development, superimposed on nutrient loads from farming and animal operations, and groundwater inputs were accelerated by changes in freshwater flow and associated, negatively reinforcing, biogeochemical responses. Regionally, chlorophyll $a$ concentrations have increased, and submersed aquatic vegetation has decreased. The system is now characterized by sustained summer picoplanktonic algal blooms, both brown
\end{abstract}

P. M. Glibert $(\bowtie) \cdot$ D. C. Hinkle

Horn Point Laboratory, University of Maryland

Center for Environmental Science, P.O. Box 775,

Cambridge, MD 21613, USA

e-mail: glibert@umces.edu

\section{B. Sturgis}

National Park Service, United States Department of the Interior, Assateague Island National Seashore,

Berlin, MD 21811, USA

R. V. Jesien

Maryland Coastal Bays Program, 9919 Stephen Decatur Highway,

Ocean City, MD 21842, USA tide and cyanobacteria. The retentive nature of this coastal lagoon combined with the reducing nature of the system will make these changes difficult to reverse if the current dual nutrient management practices are not accelerated.

Keywords Eutrophication · Algal blooms · Coastal lagoon · Ammonia/ammonium $\cdot$ Coastal Bay $\cdot$ Cyanobacteria $\cdot$

Brown tide

\section{Introduction}

The coastal embayments of Maryland and Virginia, shallow coastal lagoons, have been experiencing the impacts of eutrophication over the past decade, as evidenced by increasing nutrients, sporadic or sustained hypoxia, increased macroalgal and phytoplankton blooms, losses of submersed aquatic vegetation (SAV), among other effects (Goshorn et al. 2004; Wazniak et al. 2007; Glibert et al. 2007, 2010; Fertig et al. 2013). In addition, the phytoplankton blooms have been shown to be composed of increasing proportions of those species that are considered to be harmful algal blooms (HAB) species, including the brown tide species Aureococcus anophagefferens (Trice et al. 2004; Wazniak and Glibert 2004; Glibert et al. 2007). These trends, however, are also temporally and spatially variable, but the causes of such variability are not well understood. As is the case with many coastal regions, the human population of the coastal bays watershed has increased substantially over the past several decades and has approximately doubled since 1980 and is expected to double again in the coming decades (Wazniak et al. 2007). Moreover, summer populations of tourists add additional human pressure to the region. Nutrient loading from development and other anthropogenic changes has increased accordingly. The regional watershed has traditionally been dominated by 
farming and forestry. In addition to housing development, current land use is now a mix of intensive poultry operations, agriculture, forests, extensively ditched wetland systems, and a national park barrier island system (Boynton et al. 1996; Wazniak et al. 2007; Glibert et al. 2007). Thus, tools to assess the status and rate of change of the system are needed to guide management decisions, while rapidly changing conditions provide daunting challenges for ecosystem managers.

Coastal lagoons are fundamentally different types of estuaries than more classical river-dominated systems (Kurtz et al. 2006; Madden 2010; Glibert et al. 2010). Coastal lagoons are shallow, demonstrate strong benthic-pelagic coupling, and have minimal freshwater input as well as limited oceanic exchange. Specifically in the case of the Maryland/Virginia Coastal Bays, average depths range from 0.67 to $1.22 \mathrm{~m}$ (Boynton et al. 1996) depending on the bay region and have flushing rates on the order of $\sim 7 \%$ day $^{-1}$ (Pritchard 1969). Thus, nutrients and contaminants that enter the bay tend to stay in the bay. Furthermore, differences in the quality of the nutrient pool, the seasonal timing of delivery and the source of nutrients, as well as in the resident phytoplankton community lead to different types of algal blooms in coastal lagoons than in river-dominated estuaries (Glibert et al. 2010). Algal blooms in coastal lagoons are often comprised of picoplanktonic species, are generally sustained on regenerated or chemically reduced forms of nitrogen $(\mathrm{N})$, such as ammonium $\left(\mathrm{NH}_{4}^{+}\right)$, urea or dissolved organic nitrogen (DON), and may be sustained for long periods of time (e.g., Berg et al. 1997; LaRoche et al. 1997; Gobler et al. 2005; Lomas et al. 2001, 2004). Sustained blooms of picoplankton such as those of $A$. anophagefferens are not only HABs, but have been given a unique term, "ecosystem disruptive algal blooms" (EDABs; Sunda et al. 2006).

A monitoring program has been in place in the Maryland/Virginia Coastal Bays since the early 1990s allowing many water quality parameters to be tracked. Additionally, a Comprehensive Conservation Management Plan has been in place for nearly two decades, with goals of decreasing nutrients, increasing seagrass distributions, and maintaining viable fisheries populations (Maryland Coastal Bays Program MCBP 1999). In fact, the early years of this record (pre mid-1990s) suggested improving water quality conditions in terms of nutrient levels, with $17 \%$ of sites showing improvement in total nitrogen (TN), $50 \%$ in total phosphorus (TP), and 33\% in chlorophyll $a$ (Chl $a)$ when analyzed using linear trends (Wazniak et al. 2007), suggesting that management actions were effective. However, since the late 1990s, TN, TP, and Chl $a$ have increased (Wazniak et al. 2007), and increases in frequency and intensity of blooms of $A$. anophagefferens have also been noted (Trice et al. 2004; Glibert et al. 2007).

Here, we extend these previously documented trends in water quality parameters, with emphasis on large-scale, regional change, and we show that not only has water quality worsened, but that many of these changes occurred over a period of a few critical years during the early 2000 s. We explore the reinforcing anthropogenic, natural, biological, and biogeochemical feedbacks that contribute to sustained degradation of these water bodies. We recognize that such a large-scale approach will not fully detail the changes at local scales, some of which are, in fact, more significant than portrayed by the regional average analysis (c.f., Beckert et al. 2011; Fertig et al. 2013). A central question is: to what extent are anthropogenic changes in nutrients the cause of the decline of water quality now documented? If so, which nutrients have shown the greatest change and why do there appear to be periods of abrupt rather than gradual change?

\section{Materials and Methods}

\section{Long-Term Water Quality Data}

The analysis herein is based on data collected by the National Park Service that has conducted a monthly water quality sampling program at 18 stations throughout the Coastal Bays sub-embayments, Newport, Sinepuxent, and Chincoteague Bays, since the late 1980s (Fig. 1). The frequency of sample collection has been monthly since 1994, and thus, the bulk of the data herein are inclusive of 1994-2008 or 2009, depending on the parameter. The 18 stations were grouped into seven bay segments, based on geographic proximity, previously documented similarity in water quality trends, and on the basis of regions for which current or future management applications may be regionally relevant (Fig. 1).

The same protocols, analysis methods, and instrumentation have been used throughout all sampling years for all nutrient analyses. Whole water samples were collected and either filtered on board or stored in the dark on ice until transferred to the laboratory (within $\sim 4 \mathrm{~h}$ ), where aliquots were filtered through Whatman GF/F filters (nominally $0.7 \mu \mathrm{m}$ ) for inorganic nutrient and pigment analysis. The filtrate of precombusted filters was stored frozen for subsequent nutrient analysis; the filters were stored at $-80{ }^{\circ} \mathrm{C}$. Inorganic nutrients $\left(\mathrm{NO}_{3}{ }^{-}+\mathrm{NO}_{2}{ }^{-}\right.$, hereafter referred to only as nitrate, $\mathrm{NO}_{3}{ }^{-}$as concentrations of $\mathrm{NO}_{2}{ }^{-}$were very low; $\mathrm{NH}_{4}{ }^{+}$; phosphate, $\mathrm{PO}_{4}{ }^{3-}$; and silicate, $\left.\mathrm{Si}(\mathrm{OH})_{4}\right)$, were analyzed in the laboratories of the University of Maryland Center for Environmental Science using standard auto-analysis methods (Lane et al. 2000; Keefe et al. 2004). In addition, TN and TP were analyzed on samples that were not filtered using persulfate combustion techniques (Valderrama 1981; Bronk et al. 2000; Solórzano and Sharp 1980).

Analyses of phytoplankton $\mathrm{Chl} a$ and accessory pigments were by high performance liquid chromatography (HPLC; 
Fig. 1 Map of the Maryland/ Virginia Coastal Bays area, with inset map showing relationship to the Chesapeake Bay region. The long-term stations are indicated on the map and the circled regions show the bay segments defined in text

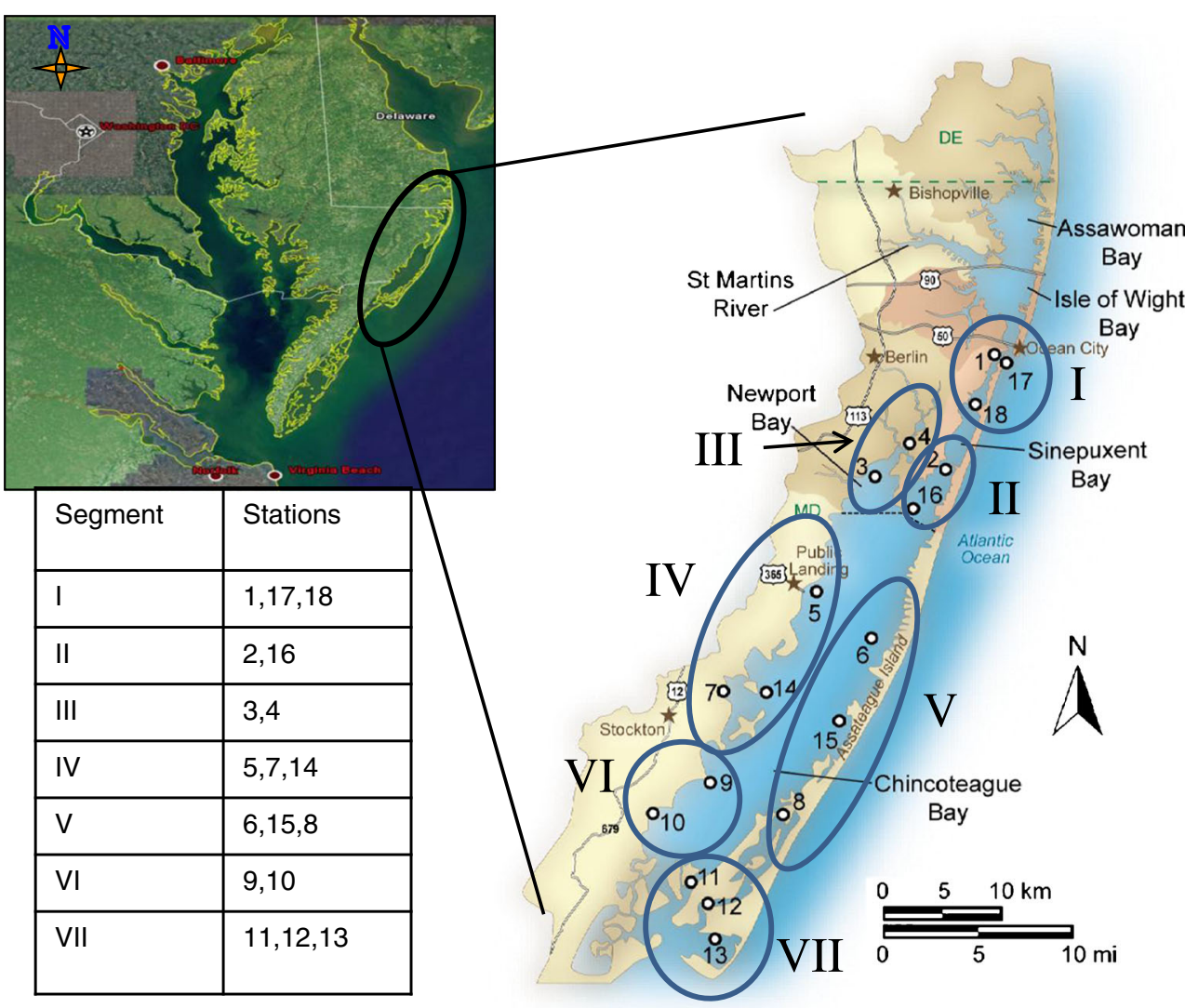

Van Heukelem and Thomas 2001). The HPLC methods evolved during the decades of monitoring as previously described by Trice et al. (2004). Although Chl $a$ data are available for the entire time course under consideration, comparative accessory pigment data are only available from 1999 onwards. Herein, we have used several common photosynthetic pigments as chemotaxonomic markers to identify changes in phytoplankton community composition (e.g., Andersen et al. 1996; Suzuki et al. 1997; Ansotegui et al. 2001). In particular, we investigated the changes in the xanthophyll 19'-butanoyloxyfucoxanthin (hereafter but-fuco) as a marker for pelagophytes such as $A$. anophagefferens (brown tide), peridinin as a marker for peridinin-containing dinoflagellates, fucoxanthin as a marker for diatoms (although recognizing that this pigment may also be present in chrysophyte and prymnesiophytes), and zeaxanthin as a marker for cyanobacteria (Kana et al. 1988; Jeffrey and Vesk 1997).

Trends in SAV were based on the Virginia Institute of Marine Sciences annual surveys (http://web.vims.edu/bio/ sav/). Methods for SAV estimation were as described in Wazniak et al. (2007) and represent single, annual estimates by bay region.

Freshwater Flow

Data for freshwater flow were derived from the United States Geological Survey (USGS) surface water discharge estimates from a nearby, gauged stream, the Nassawango Creek near Snow Hill, MD, USA. Monthly discharge data were downloaded from the USGS web site (http:// waterdata.usgs.gov/nwis/monthly, accessed April 10, 2009 and July 3, 2012). This stream does not discharge into the Coastal Bays, but it is directly adjacent to the bays and thus served as a proxy measurement of potential groundwater flows into the bays. This stream was chosen because it is the nearest site for which continual monitoring has occurred over the same time period as water quality monitoring of the Coastal Bays. This stream and the Coastal Bays are similarly influenced by regional climatic variability.

\section{Statistical Analysis}

Long-term trends were analyzed using several approaches. First, frequency distributions of the concentrations of the inorganic forms of nutrients were determined using all available data in the database $(>3,000$ data points per analyte). Second, seasonal averages were calculated to determine overall seasonal patterns. Third, annual averages were calculated by bay segments and overall trends were examined with time and linear trends were determined. Note that polynomial trend analysis was applied to an earlier portion of this time series by Wazniak et al. (2007).

In addition, cumulative sums of variability (CUSUM; e.g., Page 1954; MacNally and Hart 1997; Manly and Mackenzie 
2003; Mesnil and Petitgas 2009) values were calculated for selected parameters and compared. CUSUM analysis was conducted only on those parameters for which the time series extended $>10$ years; accessory pigment data were not included in this analysis. As background, CUSUM-transformed relationships compare accumulated differences between each measurement and their average benchmark value over time. CUSUM is, in effect, a low-pass filter for time series analysis. It provides a relatively simple and visually accentuated means to assess the degree to which values deviate from the norm over time. Herein, the $z$-score CUSUM approach of Briceño and Boyer (2010) was applied. Z-scores for all data series were calculated as each individual datum value minus the overall average of the data in the time series, divided by the overall standard deviation. To calculate CUSUM, the $z$-scores are summed through time. Downward trends are indicative of values consistently below the long-term mean, upward trends indicative of values above the long-term mean; they should not be interpreted as downward or upward "slopes." It is the change in CUSUM over time, the break points in the time series, or the comparison of CUSUM changes in one parameter relative to another, that is of interest. Absolute CUSUM values are not important to the understanding of relationships. Absolute CUSUM values will change depending on the length of the time series, as inclusion of additional data will change the "population" mean and standard deviation. CUSUM charts are particularly useful in identifying the distinct inflection points which signify a point in time when there was a shift in the relationship of the data relative to the mean. All CUSUM analyses were calculated using all available monthly data, not annual averages.

\section{Results}

\section{Nutrients}

Concentrations of $\mathrm{NO}_{3}{ }^{-}$remained very low throughout the time series, with $\sim 80 \%$ of all values having concentrations $<1 \mu \mathrm{M}-\mathrm{N}$ (Fig. 2a). In contrast, for $\mathrm{NH}_{4}^{+}, \sim 35 \%$ of all samples had values $<1 \mu \mathrm{M}-\mathrm{N},>40 \%$ of samples had values $>2 \mu \mathrm{M}$ $\mathrm{N}$, and $\sim 10 \%$ of all samples had values $>10 \mu \mathrm{M}-\mathrm{N}$ (Fig. $2 b$ ). For $\mathrm{PO}_{4}{ }^{3-},>60 \%$ of all samples had concentration values $<0.50 \mu \mathrm{M}-\mathrm{P}$ (Fig. $2 \mathrm{c}$ ).

Seasonally, mean concentrations of $\mathrm{NH}_{4}^{+}$remained $>2 \mu \mathrm{M}$ $\mathrm{N}$ throughout the year, while mean concentrations of $\mathrm{NO}_{3}{ }^{-}$ generally remained $<1 \mu \mathrm{M}-\mathrm{N}$ year-round (Fig. $3 \mathrm{a}-\mathrm{c}$ ). The highest seasonal variability was found in $\mathrm{PO}_{4}{ }^{3-}$, which also displayed considerable station-to-station variability (Fig. 3a-c).

In general, both $\mathrm{N}$ and $\mathrm{P}$ annually and regionally averaged concentrations increased throughout the bay over time, but the trends differed by nutrient form and bay segment. Averaged TN increased in all bay segments except segment

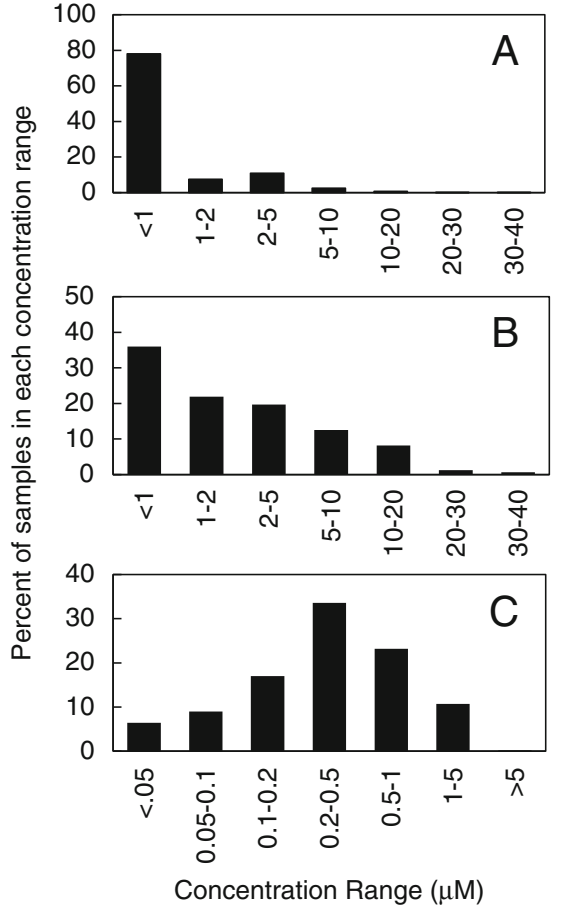

Fig. 2 Percent of all samples ( $n=>3,000$ for each parameter) analyzed monthly from 1994 to 2008 in each concentration category indicated for a nitrate + nitrite $\left(\mathrm{NO}_{3}{ }^{-}+\mathrm{NO}_{2}{ }^{-}\right)$, b ammonium $\left(\mathrm{NH}_{4}{ }^{+}\right)$, and $\mathbf{c}$ phosphate $\left(\mathrm{PO}_{4}{ }^{3-}\right)$

III (Fig. 4). These increases were $\sim$ a factor of 2 in most regions. While no significant trends were observed for TN for segment III, this region had the highest overall concentrations of TN relative to other regions on the bays. Averaged TP increased with time only in segments IV, V, and VI, while trends with time for the other segments were not significant (Fig. 4). Significant increases in annually averaged $\mathrm{NH}_{4}{ }^{+}$concentrations, in some cases more than an order of magnitude, were observed in all bay segments (Fig. 5). For $\mathrm{NO}_{3}^{-}$, significant increases were only observed for segment $\mathrm{V}$, and even then, the concentrations remained $<1 \mu \mathrm{M}$ on an annual basis (Fig. 5). For $\mathrm{PO}_{4}{ }^{3-}$, in addition to the regions where TP increased, there were also positive, significant increases in segments II and III with time, with some of these increases being as much as a factor of $\sim 3$ (Fig. 6). Trends in annual $\mathrm{Si}(\mathrm{OH})_{4}$ concentrations were variable (Fig. 6), and a significant increase was only observed in segment IV.

While both mean $\mathrm{N}$ and $\mathrm{P}$ tended to increase with time in most bay segments, the change in proportion of $\mathrm{N}$ to $\mathrm{P}(\mathrm{N} / \mathrm{P}$ ratios) was not nearly as large, that is, the increases in both nutrients were proportional. Significant increases in TN/TP were only noted with time for segments I and VII and in DIN/DIP in segment VII also; all other segments showed no significant change with time in TN/TP or DIN/DIP (Fig. 7). There were no instances in which the N/P ratio (in any form) decreased with time; thus, there were no regions where the increase in $\mathrm{P}$ exceeded that of $\mathrm{N}$ over the time course, 
Segment I

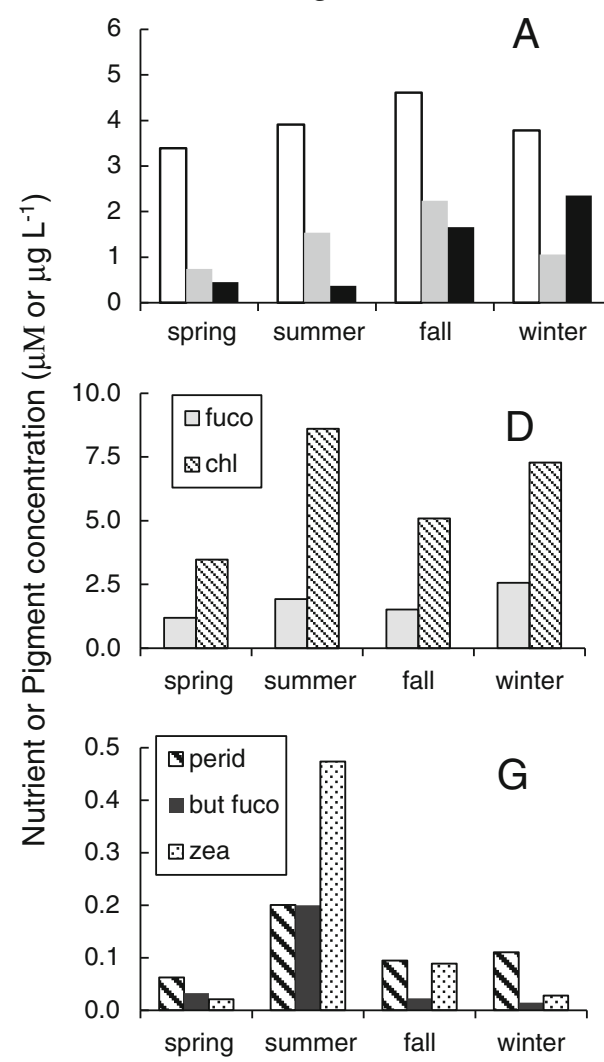

Segment IV
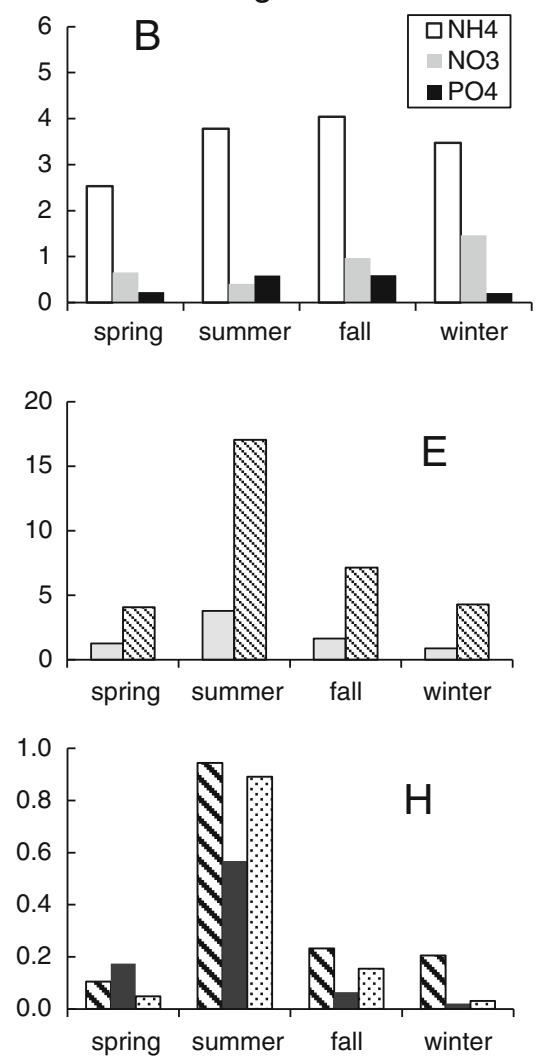

Segment VII
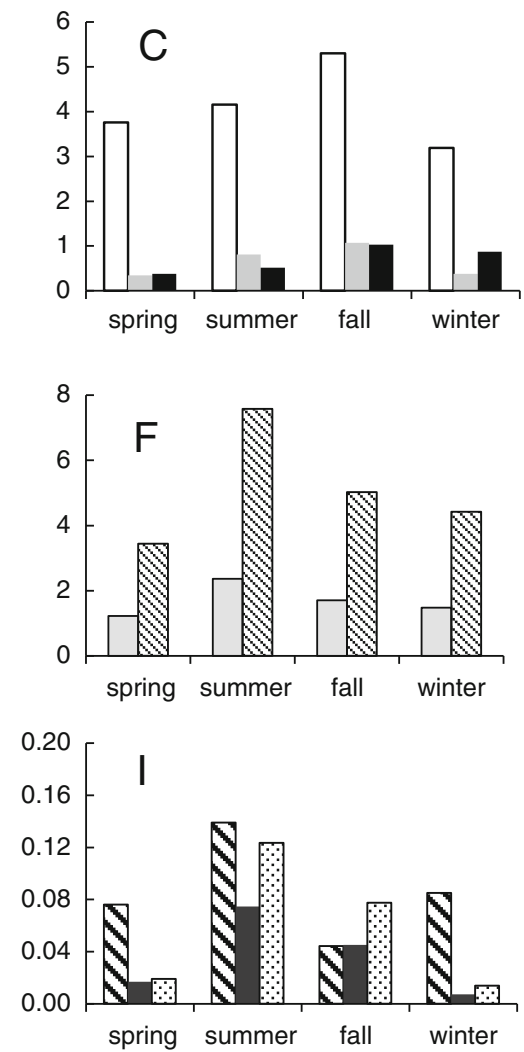

Fig. 3 Seasonally averaged concentrations of inorganic nitrogen and phosphorus $(\mathbf{a}-\mathbf{c})$, chlorophyll $a(\mathbf{d}-\mathbf{f})$, and the major pigments $(\mathbf{d}-\mathbf{i})$ analyzed here for representative bay segments (segment I: a, d, $\mathbf{g}$; segment IV: b, e, h; segment VII: c, f, i)

although within the time course, there were short periods for some regions where such patterns were observed.

The CUSUM calculations for inorganic nutrients illustrate clearly the overall trends of nutrient values falling below the mean in the first part of the time series and values falling above the mean in the second part of the time series (Fig. 8). CUSUM, however, provides further power to differentiate inflection periods that differed with nutrient form and with bay segment. For $\mathrm{NO}_{3}{ }^{-}$, the first years of the CUSUM charts for all segments show considerable variability (Fig. 8a). After this period of variability, values for all bay segments show a general decline in CUSUM $\mathrm{NO}_{3}{ }^{-}$up to 2003 (i.e., values below the long-term mean), when a reversal in trend was noted. It is important to recall, however, that overall concentrations of $\mathrm{NO}_{3}{ }^{-}$were low throughout the time series, so small changes may accentuate trends. For $\mathrm{NH}_{4}{ }^{+}$, all segments showed a clear declining CUSUM trend until 2001 (i.e., concentrations below the long-term mean), a short uptick 2001 , followed by another decline up to 2003 , and then a period through 2008 during which CUSUM values trended upwards (i.e., concentrations above the long-term mean; Fig. 8b). In contrast to $\mathrm{NO}_{3}{ }^{-}$, the CUSUM values for $\mathrm{NH}_{4}{ }^{+}$for all bay segments were generally consistent in trends and values.
Trends in CUSUM $\mathrm{PO}_{4}{ }^{3-}$ generally declined until about 2001 (i.e., concentrations below the long-term mean), although with variable slopes for different bay segments, then increased abruptly and either continued to increase or remained roughly constant (Fig. 8c). For bay segment I, the initial trend was significantly more pronounced. Trends in $\mathrm{Si}(\mathrm{OH})_{4}$ CUSUMs also displayed a downward trend until 2001 , then an upward trend until roughly 2003 , and then near constant values (Fig. 8d). Seasonality was more apparent in CUSUMs of $\mathrm{Si}(\mathrm{OH})_{4}$ than in any other nutrient.

\section{Pelagic and Benthic Primary Producers}

Half of all Chl $a$ values of the entire data set were $<5 \mu \mathrm{g} \mathrm{L}{ }^{-1}$ (Fig. 9a). However, when higher Chl $a,>5 \mu \mathrm{g} \mathrm{L}^{-1}$, did develop, it was generally a summer phenomenon (Fig. 9b). More than $75 \%$ of the incidences of Chl $a>5 \mu \mathrm{g} \mathrm{L}^{-1}$ occurred in the months of June through September; a spring bloom accumulation of Chl $a$ is generally not observed in these bays. This trend is reflected in the accessory pigment trends as well (Fig. 3d-i).

Changes with time in Chl $a$ were highly variable by bay segment, but, in spite of the increases in TN and TP throughout much of the Bay, significant linear trend increases in Chl $a$ were only observed in segments IV, VI, and VII (Fig. 10). 
Fig. 4 Annual average concentrations of total $\mathrm{N}(\mathrm{TN}$, micromolar) and total $\mathrm{P}$ (TP, micromolar) for segments indicated. [Panels are arranged geographically comparable to the Bay segments in Fig. 1]. Lines are linear trend lines; bold lines represent trends that are significant at $p<0.05$. Note that while the scales differ between panels, the ratio of the primary $Y$-axis to the secondary $Y$-axis remains the same in all panels. Significant increasing trends were observed in most segments for both nutrients

Fig. 5 As for Fig. 4 except for ammonium $\left(\mathrm{NH}_{4}{ }^{+}\right.$, micromolar) and nitrate plus nitrite $\left(\mathrm{NO}_{3}{ }^{-}\right.$, micromolar). Increases in $\mathrm{NH}_{4}^{+}$ were significant in every segment; increases in $\mathrm{NO}_{3}{ }^{-}$ were significant only in segment V
Total nitrogen and

Total phosphorus
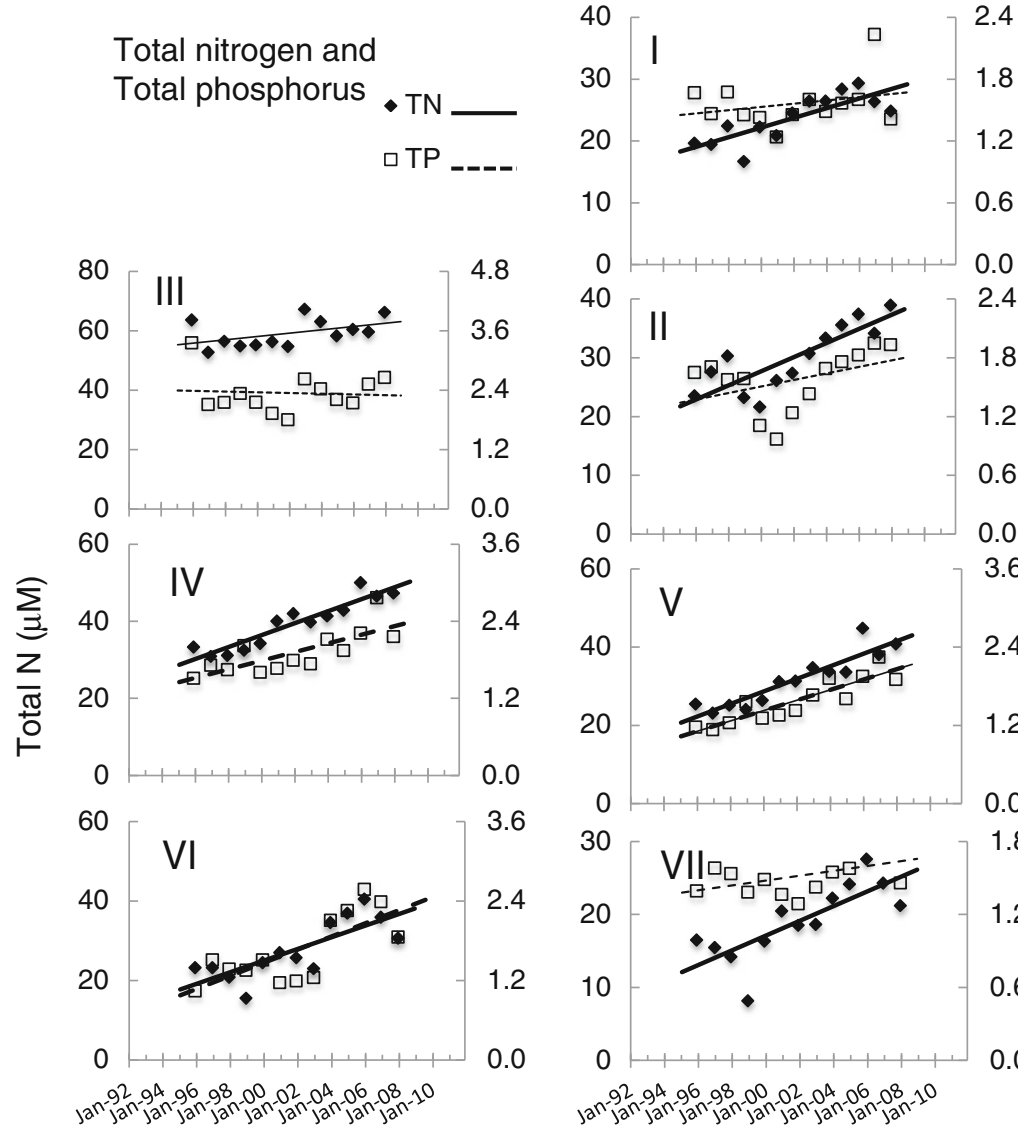

10

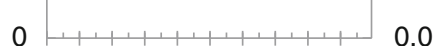

60

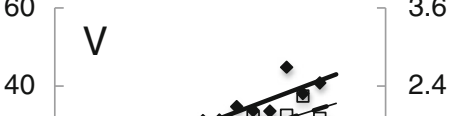
뜡

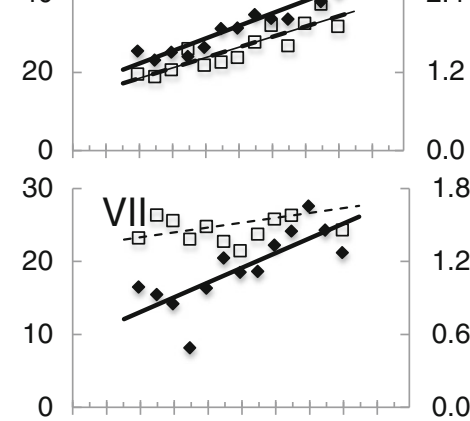

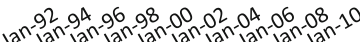

.0

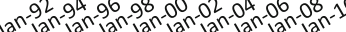

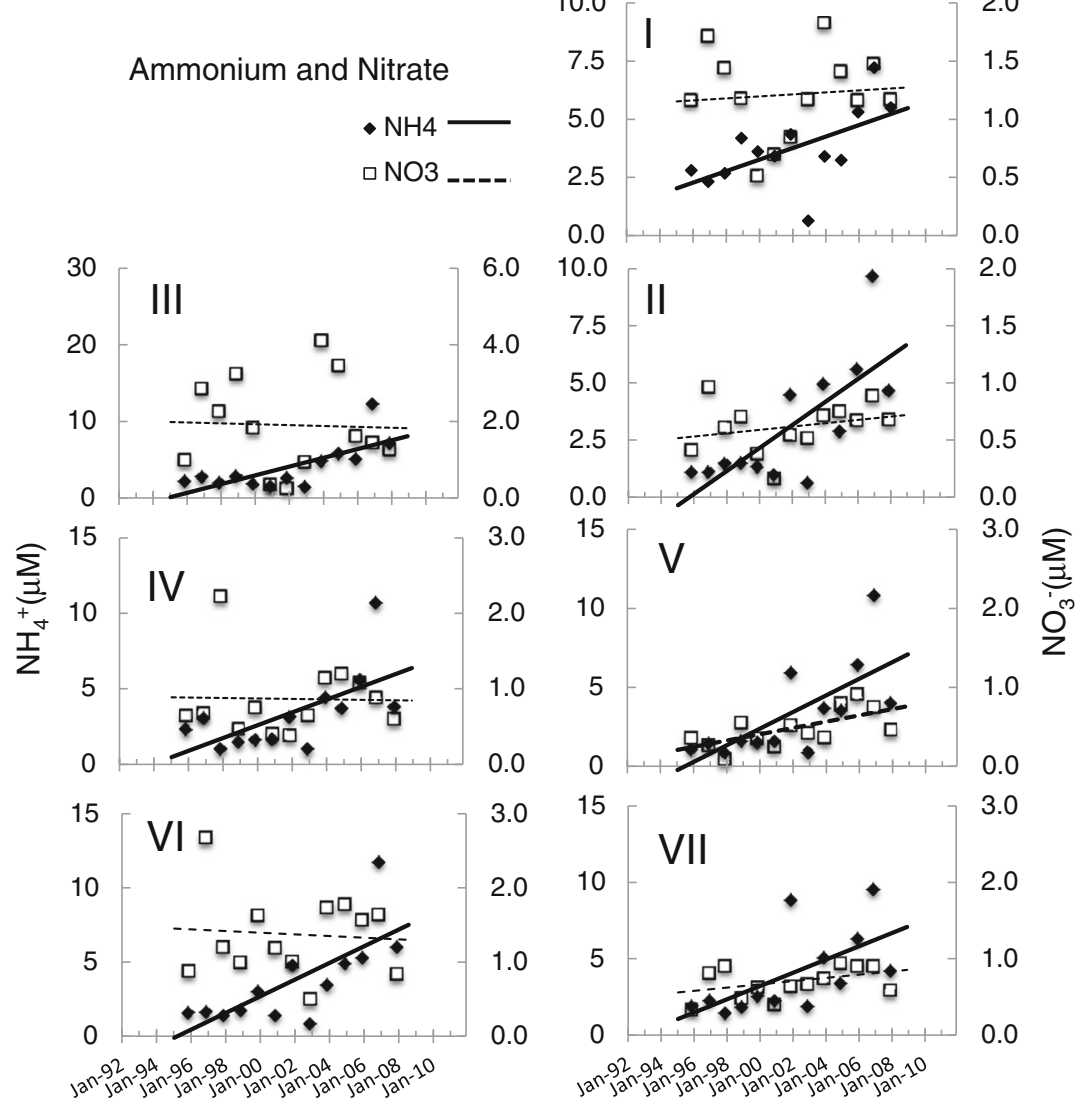


Fig. 6 As for Fig. 4, except for phosphate $\left(\mathrm{PO}_{4}{ }^{3-}\right.$, micromolar) and silicate $\left(\mathrm{Si}(\mathrm{OH})_{4}\right.$, micromolar). Increases in $\mathrm{PO}_{4}{ }^{3-}$ were significant in all but segments I and VII. Increases in $\mathrm{Si}(\mathrm{OH})_{4}$ were only significant in segment IV

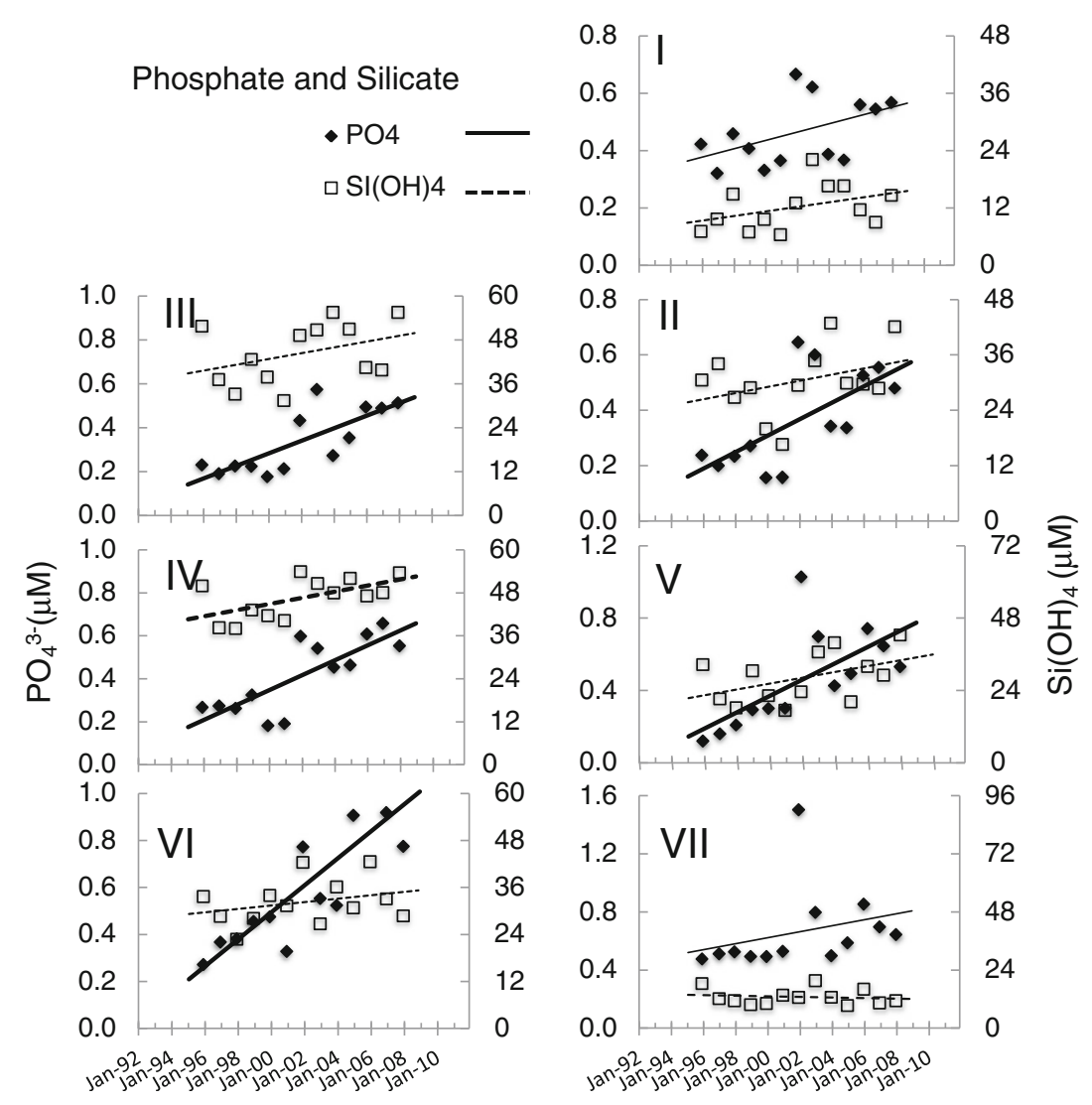

The CUSUM trends for Chl $a$ for all bay segments show similar trends: values were less than the long-term mean until early 2003, after which values were above the longterm mean (Fig. 11a). The inflection points in the CUSUM $\mathrm{Chl} a$ trends approximate the period when SAV began to decline (Fig. 11b). Estimates of changes in coverage of SAV are only available for some of the bay segments, but all show an increase with time until the early 2000 s, then a decline. Survey data for SAV are not available for 2005 due to logistic problems, but overall, 2005 can be considered a year of substantial SAV loss.

There have also been pronounced changes in the phytoplankton composition over time as suggested by the change in phytoplankton pigment composition. Data on changes over time in accessory pigments are available only for the latter years for which Chl $a$ data are available, but such data suggest that the changes in phytoplankton were variable by region (Figs. 12 and 13). Zeaxanthin, indicative of cyanobacteria, increased significantly with time for segments II and VII, while the other segments showed no significant linear trend (Fig. 12). There were increasing trends in annual fucoxanthin concentrations, indicative of diatoms, also for segments II and VII (Fig. 13). Changes in peridinin, indicative of peridinincontaining dinoflagellates, were highly variable both within and between sites; there was a decline over time in segment III (Fig. 13). Interestingly, there were no significant increases or decreases in but-fuco (indicative of brown tide, $A$. anophagefferens) in any bay segment (Fig. 12).

Freshwater Flow and Comparisons with Nutrient Changes

The time series encompassed by these data reflect variably wet and dry periods (Fig. 14). When transformed into $z$-score CUSUM trends, the oscillation between dry years (19951996), variably wet (through mid-1998), then drier (through $\sim 2002$ ), and then wet again through $\sim 2007$ is readily apparent (Fig. 14). Superimposed on this general trend were additional short-term fluctuations between wet and dry periods.

The CUSUM time course for freshwater discharge was herein deconstructed into 11 time periods representing wet and dry periods lasting more than a season (Fig. 14). [Shortterm oscillations of wet and dry $<1$ year were disregarded for this analysis because seasonal trends could override climate variability trends]. For $\mathrm{NH}_{4}^{+}$, average concentrations for the wet periods later in the time course were higher than those earlier in the time course for wet periods, but during dry periods, the increase in mean concentrations in periods 9 and 11 compared to those earlier in the time course is even more striking (Fig. 15a, b). Concentrations of $\mathrm{NH}_{4}^{+}$averaged $2.03 \mu \mathrm{M}-\mathrm{N}$ during the wet period early in the time course and more than doubled to $4.67 \mu \mathrm{M}-\mathrm{N}$ later in the time course; however, the same comparison during the dry periods shows a greater than four-fold change, from $2.07 \mu \mathrm{M}-\mathrm{N}$ in the early 


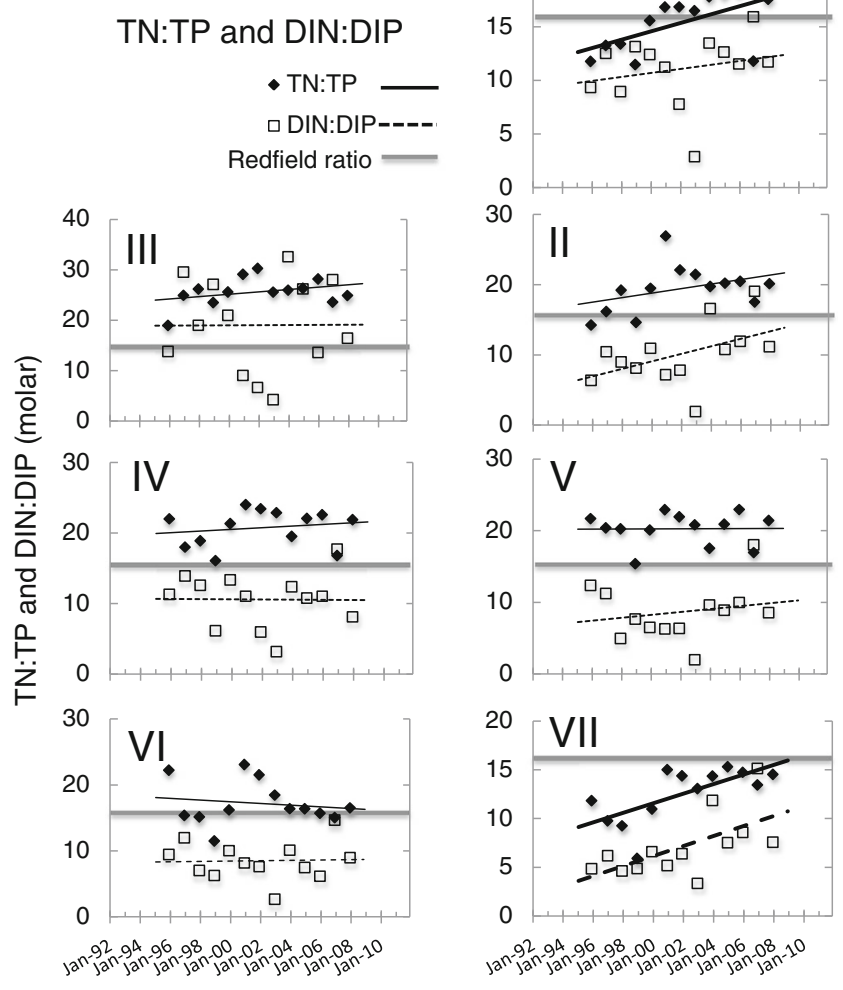

Fig. 7 As for Fig. 4 except for the ratios of total nitrogen/total phosphorus (TN/TP, molar) and dissolved inorganic N/dissolved inorganic $\mathrm{P}$ (DIN/DIP, molar). Note that the changes in these ratios were generally not significant over time except for TN/TP (segments I and VII) and DIN/DIP (segment VII). In all cases, the annual average TN/ $\mathrm{TP}$ ratios was greater than the DIN/DIP ratios, and in almost all regions (segment III excepted), the DIN/DIP ratios fell below the Redfield ratio (shown as horizontal line $=16$ )

periods to $8.26 \mu \mathrm{M}-\mathrm{N}$ in later periods, on average. For $\mathrm{NO}_{3}{ }^{-}$, average concentrations of the latter wet periods were lower than the wet period earlier in the time course, an insignificant change from 1.75 to $1.29 \mu \mathrm{M}-\mathrm{N}$ on average, while for dry periods, average concentrations increased from $0.47 \mu \mathrm{M}-\mathrm{N}$ early in the time course to $0.81 \mu \mathrm{M}-\mathrm{N}$ later (Fig. 15c, d). For $\mathrm{NO}_{3}{ }^{-}$, because the overall concentrations were so much lower than those of $\mathrm{NH}_{4}{ }^{+}$, the region-to-region variability appears greater. For $\mathrm{PO}_{4}{ }^{3-}$, a near doubling in average concentrations in wet periods later in the course compared to early in the time course can be seen $(0.34 \mu \mathrm{M}-\mathrm{P}$ early periods versus $0.65 \mu \mathrm{M}$ $\mathrm{P}$ later periods), but no substantial differences were apparent when dry periods were compared $(0.58 \mu \mathrm{M}-\mathrm{P}$ early periods versus $0.77 \mu \mathrm{M}-\mathrm{P}$ later periods; Fig. 15e, f).

\section{Discussion}

The analysis herein has taken a large-scale perspective of the regional changes in this ecosystem. Such an approach helps to identify large-scale patterns of change, yet may fail to reveal significant trends that occur at more local scales. Different clustering of regions may have resulted in somewhat different localized trends. Indeed, individual trends for several of the original 18 sites (not shown) are not as strong when aggregated within the regions. Furthermore, this analysis has focused on annual average trends, thus blurring any differences in trends that have occurred seasonally. Further analysis of local scale trends will be important as these results are applied in the development of nutrient loads and criteria for nutrient reduction strategies. A recent, more detailed analyses of the Newport Bay (subregion of region III) and Johnson Bay (subregion of region IV) have been provided by Beckert et al. (2011) and Fertig et al. (2013).

The large-scale, long-term trends of nutrients and phytoplankton abundance and community composition in this analysis reveal several striking patterns and relationships. Most apparent in these results is the seemingly abrupt change in the systems' ecology in the early 2000s, with increasing $\mathrm{Chl} a$ accumulation in some bay segments, increasing concentrations of $\mathrm{NH}_{4}{ }^{+}$in all bay segments, loss of $\mathrm{SAV}$, and changes in phytoplankton community composition. Although the raw data were herein analyzed using linear trends, consistent inflection points were shown in the CUSUM analysis. Previous analyses of this data set, in which trends through 2003 were examined (Wazniak et al. 2007), also suggested that any improvements in water quality that had been established in the 1990s were rapidly being reversed and that water quality trends were declining by early 2000 .

Such abrupt changes are analogous to those often described for freshwater systems, in which productive lakes can undergo a change from one stable state to another in seemingly rapid fashion (sensu Scheffer et al. 1993, 2003). Stable state theory states that a system will develop a stable state condition, i.e., homeostasis will prevail, until an environmental change or disturbance occurs. This change alters the positive reinforcing feedbacks of homeostasis, and the system is shifted to a new stable state: hysteresis overcomes homeostasis (Scheffer et al. 1993; Scheffer and Carpenter 2003). Furthermore, communities may not return to their original state when the disturbance is removed. Stable state theory is being applied in systems where there are efforts to restore macrophyte dominance in systems that have become dominated by phytoplankton as a consequence of increased eutrophication (e.g., Bachmann et al. 1999; Tátrai et al. 2009; Poor 2010). In this case, while anthropogenic stresses were increasing over the duration of the time series, the bay ecology appeared to reach a tipping point in the early 2000 s.

This paper extends the analyses of Wazniak et al. (2007) and Glibert et al. (2007) in which the declining water quality trends of these bays were first highlighted. We highlight several overarching trends, then potential physical and biogeochemical mechanisms and drivers are then explored. 

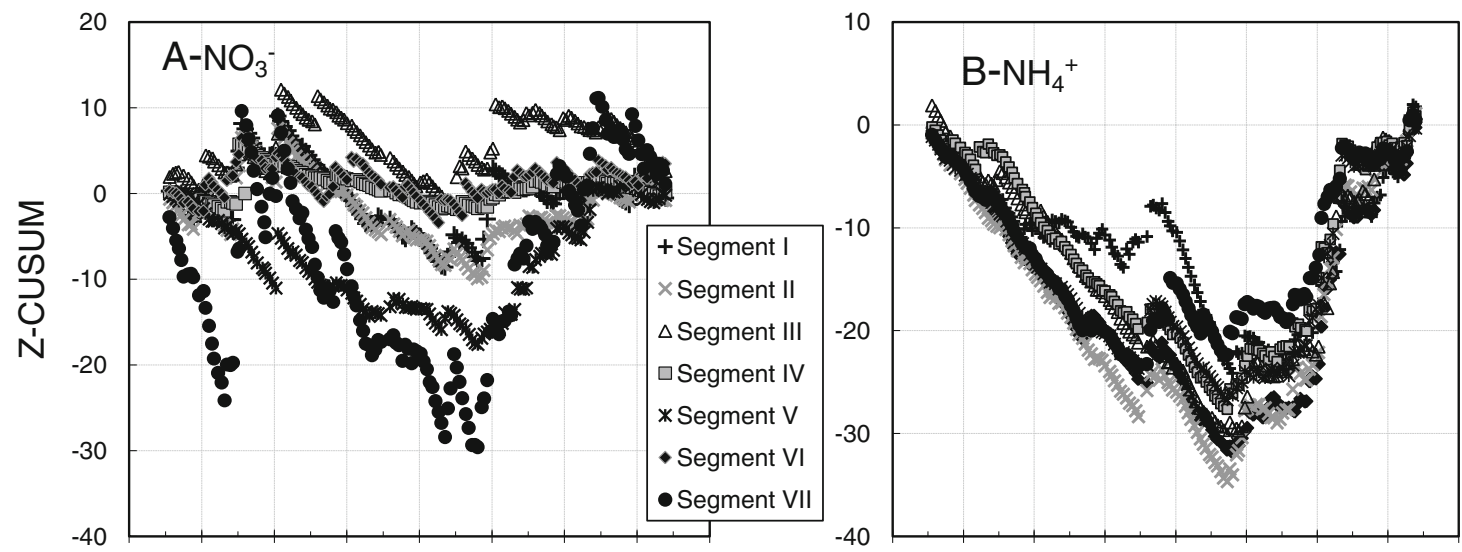

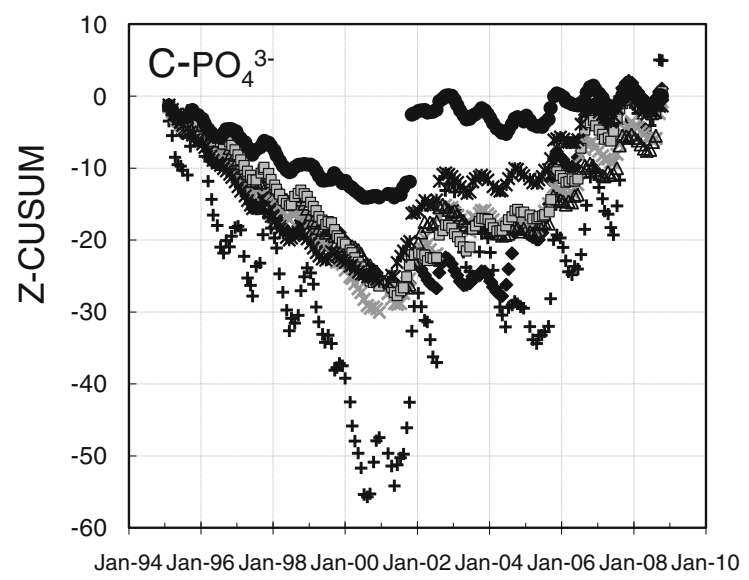

Fig. 8 Cumulative sums of variability (CUSUM) for inorganic nutrients over time for all bay segments: $\mathbf{a ~} \mathrm{NO}_{3}{ }^{-}, \mathbf{b} \mathrm{NH}_{4}{ }^{+}, \mathbf{c} \mathrm{PO}_{4}{ }^{3-}$, and $\mathbf{d}$ $\mathrm{Si}(\mathrm{OH})_{4}$. Z-CUSUM values were calculated based on monthly data. Note that in all cases, there was a general downward trend in CUSUM

\section{Overarching Trends}

The characterization of water quality useful for management is a contentious issue, as not all parameters are of equal value in characterizing water quality, nor do they necessarily trend equally. Here, several overarching trends are highlighted that should be of value to managers charged with characterizing eutrophic condition and effectiveness of nutrient strategies.

First, nutrient concentrations have increased through the bay in the time period of this analysis, but not all forms of nutrient have increased similarly. For TN (Fig. 4), values have increased more than approximately twofold and these trends have been in near linear fashion in most regions of the bay since the beginning of the time series explored here, suggesting sustained anthropogenic pressure. For $\mathrm{NH}_{4}{ }^{+}$, the increase in many parts of the bay is even greater, reaching an order of magnitude in just over a decade. Trends in $\mathrm{NH}_{4}{ }^{+}$ (Fig. 5), while significant for all bay segments when calculated using a linear model, actually show that the increase only began in a substantive and sustained way in 2003 , as

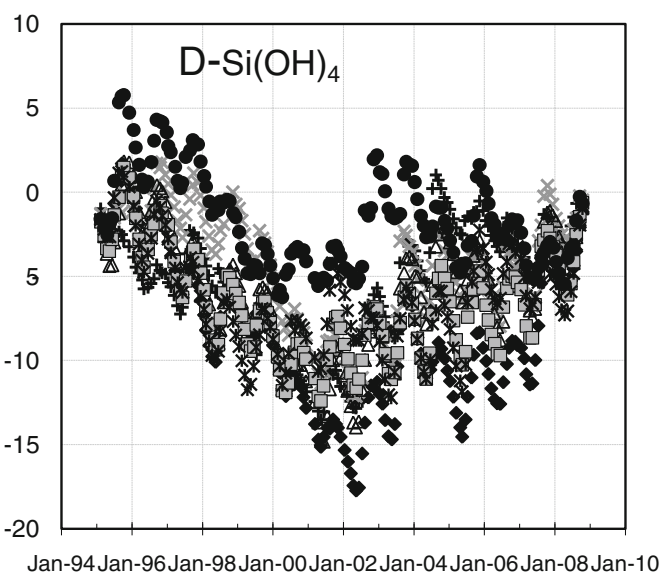

for the first part of the time series, and then an upward trend in CUSUM, indicating values below the long-term mean shifting to values above the long-term mean

reflected in the CUSUM trends (Fig. 8). In contrast, concentrations of $\mathrm{NO}_{3}{ }^{-}$, with one regional exception, have remained roughly constant, and very low, over time. Increases in most bay regions in TP have been similar in proportion to those of TN in most of the bay, leading to little change in N/P ratios, when calculated using either TP or $\mathrm{PO}_{4}{ }^{3-}$ values (Fig. 7). The primary exception to this generalization is the lower bay segment VII where ratios of N/P increased significantly.

Second, the trends were bay-wide. While there were regional differences in the extent to which different nutrients or their ratios changed with time, the directionality of all nutrients in all bay segments was similar even when linear trends did not support significance in these changes. For all inorganic nutrients, the overall shapes of the CUSUM curves (Fig. 8) for each region suggested general consistency in trends. Of particular concern is the apparent increasing degradation of the regions in the southern part of Chincoteague Bay, regions that had previously been characterized as having "good" to "excellent" water quality based on the multiparameter eutrophication index of 

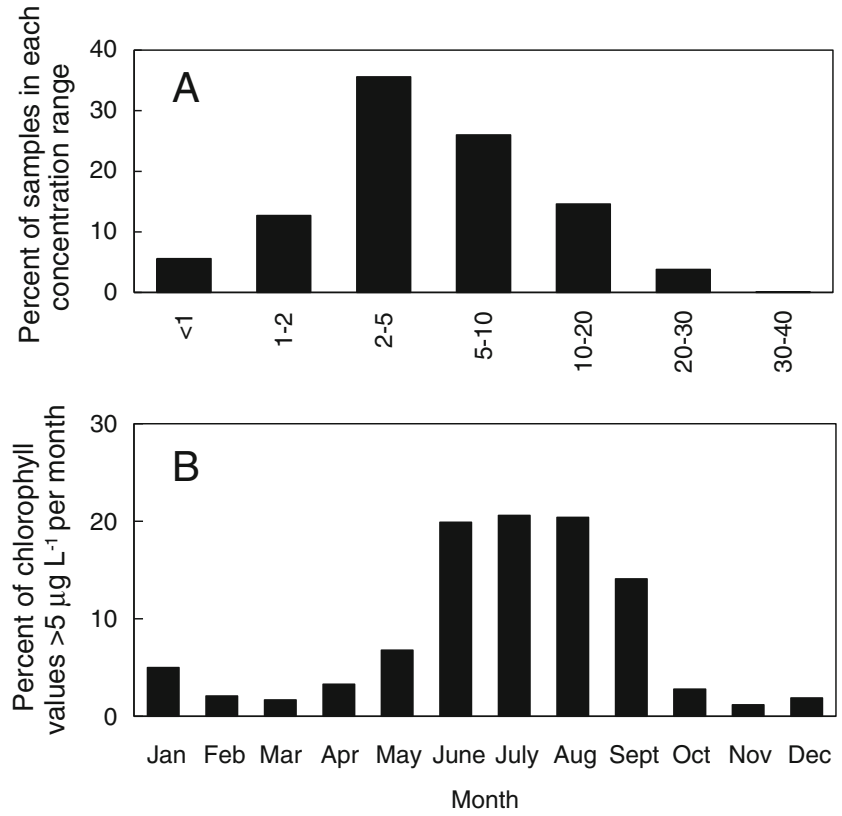

Fig. 9 a Percent of all samples $(n>3,000)$ analyzed monthly from 1994 to 2008 in each concentration category indicated for chlorophyll $a(\mathrm{Chl} a)$. b Percent of all Chl $a$ values with values $>5 \mu \mathrm{g} \mathrm{L}^{-1}$ as a function of the month during which they were collected. This illustrates that blooms, when they do occur, are a summer phenomenon

Wazniak et al. (2007). The more northern regions, including Newport Bay, have long had degraded water quality
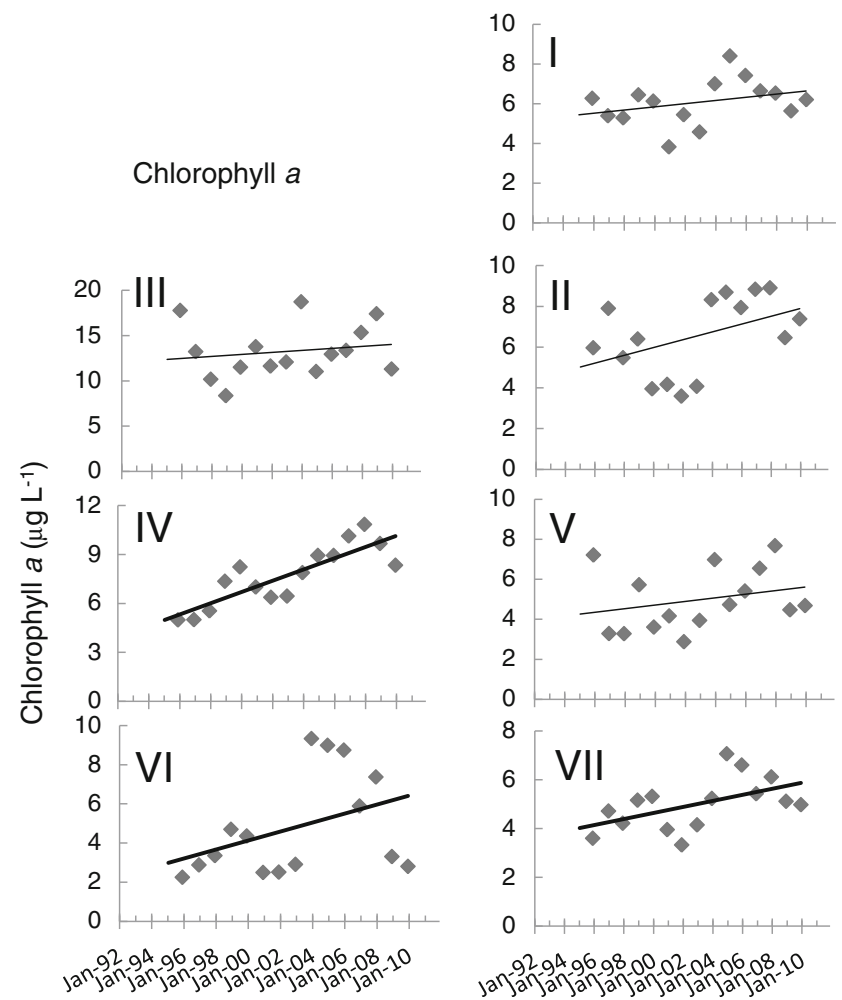

Fig. 10 As for Fig. 4, except for Chl $a$ (microgram per liter). Note the significant increasing trends in segments IV, VI, and VII
(Wazniak et al. 2007; Beckert et al. 2011). Within these regions, particularly, are several sites where more significant increasing trends are revealed from individual site analysis not shown here.

Third, these results are consistent with the emerging understanding that nutrient dynamics in coastal lagoons differ from those of classic river-dominated estuaries. Of particular concern for coastal lagoons is increasing concentrations of chemically reduced $\left(\mathrm{NH}_{4}{ }^{+}\right.$and DON), compared to oxidized $\mathrm{N}\left(\mathrm{NO}_{3}{ }^{-}\right.$or $\left.\mathrm{NO}_{2}{ }^{-}\right)$. All bay segments had significant increases in annually averaged $\mathrm{NH}_{4}{ }^{+}$concentrations, but only one region had an increase in average concentrations of $\mathrm{NO}_{3}{ }^{-}$(Fig. 5). In fact, the trend in $\mathrm{NH}_{4}{ }^{+}>$ $\mathrm{NO}_{3}{ }^{-}$was enhanced with time as $\mathrm{TN}$ loading increased, suggestive that either the TN loading was not in the form of $\mathrm{NO}_{3}{ }^{-}$, or that there was a significant biogeochemical processing of $\mathrm{NO}_{3}{ }^{-}$, leading to $\mathrm{NH}_{4}{ }^{+}$, that may have acted synergistically with anthropogenic loading, as discussed in more detail below. Whereas concentrations of $\mathrm{NO}_{3}{ }^{-}$in many riverine systems can exceed many tens of $\mu \mathrm{M}$ (e.g., Chesapeake Bay, Kemp et al. 2005; Neuse River Estuary, Christian et al. 1991 and Burkholder et al. 2006), lagoonal systems - as illustrated here and elsewhere - tend not to have elevated $\mathrm{NO}_{3}{ }^{-}$concentrations (Boyer et al. 1999; Burkholder et al. 2006; Glibert et al. 2007, 2010). Indeed, $80 \%$ of all values of $\mathrm{NO}_{3}{ }^{-}$were $<1 \mu \mathrm{M}-\mathrm{N}$ in this time series. In addition to $\mathrm{NH}_{4}{ }^{+}$, organic forms of $\mathrm{N}$ and $\mathrm{P}$ tend to dominate the nutrient pool in lagoons compared to their respective inorganic nutrient forms (Boyer et al. 1999, 2006; Glibert et al. 2007). The increasing trends of DON and their effects have previously been described (Glibert et al. 2007).

Fourth, these data suggest that the increasing trend in brown tide that was so prevalent during the early 2000 s appears to have been dampened, at least when the data are viewed from the regional perspective. While brown tide (as detected using the pigment but-fuco) is present and abundant in many segments of the bay, the intensity of the blooms has not been increasing, except in the southernmost region of the bay when viewed from the regional scale. Rather, cyanobacteria, as indicated by the change in zeaxanthin (Fig. 12), as well as dinoflagellates, indicated by the change in peridinin, and/or diatoms, indicted by the change in fucoxanthin (Fig. 13) appear to be increasing in some segments of the bay, especially segments II and VII. Microscopic enumeration (not shown) confirms that the dominant cyanobacteria are the picoplankton Synechococcus. The trends shown herein are also consistent with other coastal lagoons in having the highest $\mathrm{Chl} a$ accumulation in the summer months, rather than in the spring (Glibert et al. 2010).

From a management perspective, these trends underscore the importance of characterizing different forms of nutrient and of understanding the compositional changes in $\mathrm{Chl} a$. 
Fig. 11 a Cumulative sums of variability (CUSUM) for Chl $a$ over time for all bay segments. Z-CUSUM values were calculated based on monthly data. Note the overall downward trend until 2003, followed by an upward trend for all segments, suggestive of values below the long-term mean in the first half of the time series, followed by values above the long-term mean subsequently. b Long-term trends in coverage of SAV in segments for which such data are available. The numbers and arrows on the graph indicate the bay segment and the corresponding axis on which the data are plotted. SAV decline corresponded in time with Chl $a$ increases
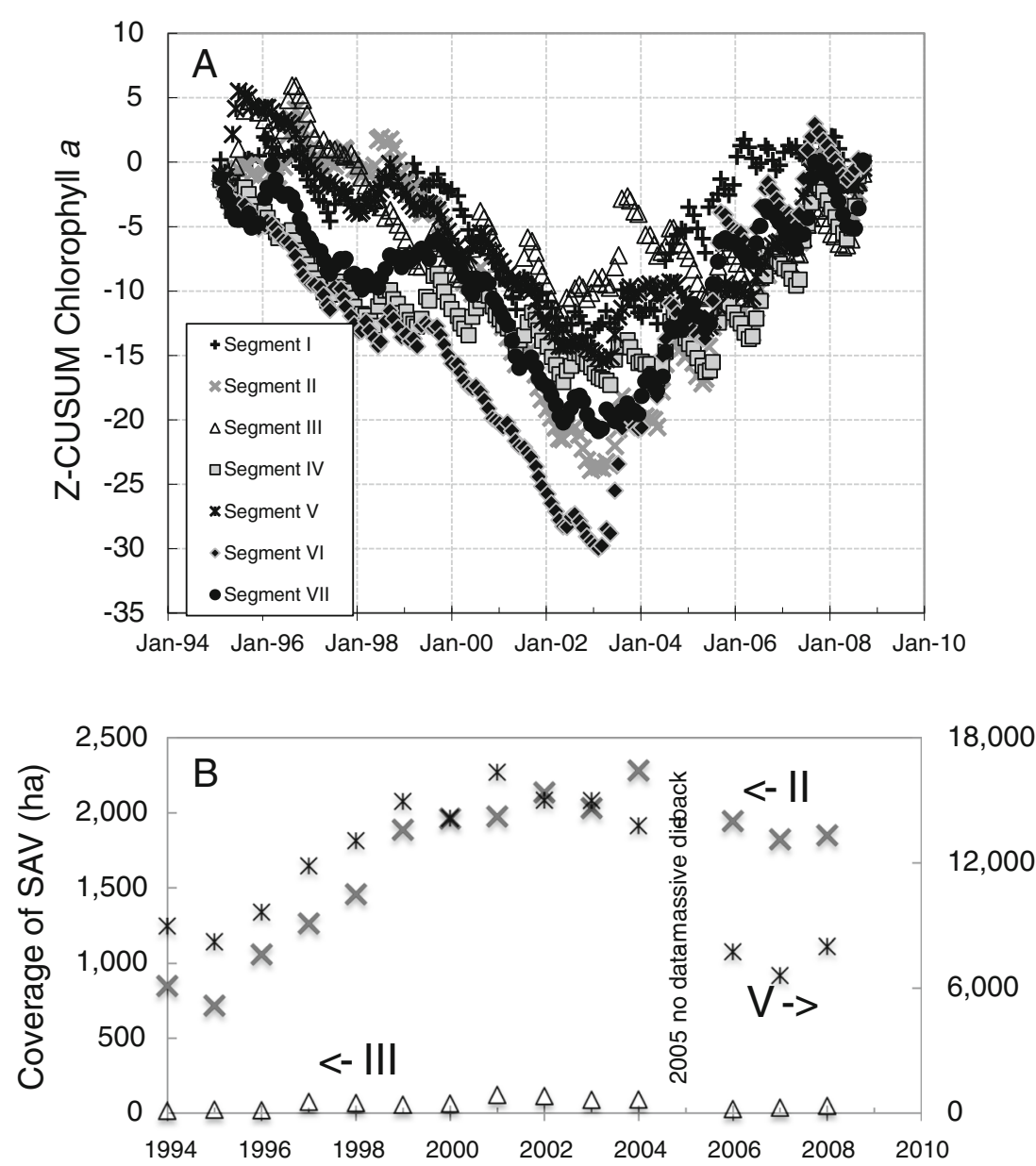

For example, with many monitoring programs moving toward cost-saving measures by reducing the numbers of parameters monitored or application of in situ nutrient detection of a single form of $\mathrm{N}$, a program that relied solely on $\mathrm{NO}_{3}{ }^{-}$monitoring, for example, would have been totally ineffective in elucidating the trends reported herein. Furthermore, understanding changes in the composition comprising Chl $a$ are helpful in understanding absolute Chl $a$ values and their changes over time. Recognizing that the dominant phytoplankton in this system are picoplankton, either brown tide or cyanobacteria, helps to understand potential disruption to the food web. EDABs do disrupt food webs. These fundamental differences in blooms between lagoons and river-dominated estuaries have important implications for nutrient management as well as for the development of estuarine nutrient criteria for these systems.

\section{Drivers of Change}

Changes in $\mathrm{PO}_{4}{ }^{3-}$ and in $\mathrm{NH}_{4}{ }^{+}$appeared to have occurred relatively abruptly, or in step function, around the years 2001 to 2003, although evidence of some changes is apparent in earlier years as well (Wazniak et al. 2007). In general, poultry operations and agricultural practices have not changed significantly over the past decade, except that there has been increasing pressure for application of best management practices, and thus, it is not likely that these land uses alone would have led to such abrupt changes, although these operations are likely major contributors to overall nutrient loads (Beckert et al. 2011; Fertig et al. 2013). While TN concentrations have been found to be very high in tributary streams adjacent to poultry farms $(\sim 50-200 \mu \mathrm{M}$ $\mathrm{N})$, there has been no appreciable change in the total numbers of poultry produced or in the numbers of farms in the past decade (United States Department of Agriculture USDA 2007; Fertig et al. 2013). There has been an increase in the use of urea-based fertilizers, and some of the sites receiving runoff from poultry farms have previously been also shown to have some of the highest regional concentrations of urea and/or $\mathrm{NH}_{4}^{+}$(Glibert et al. 2005a, 2007). Measurements of atmospheric deposition since 2000, based on the National Atmospheric Deposition program, suggest that $\mathrm{NO}_{3}{ }^{-}$is decreasing and $\mathrm{NH}_{4}{ }^{+}$from deposition is stable for the Coastal Bays (NADP data http://nadp.sws.uiuc.edu/ sites/ntn/NTNtrends.html?siteID=MD18). That septic $\mathrm{N}$ loading is increasing is well established from the increasing 


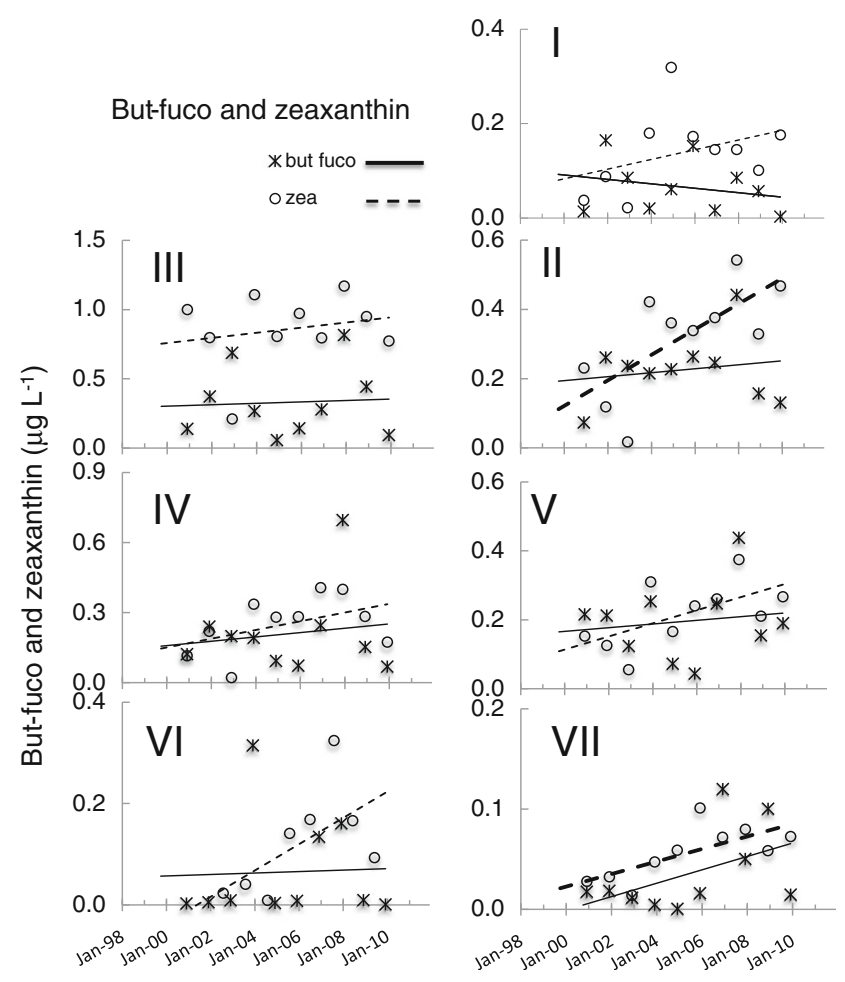

Fig. 12 As for Fig. 4, except for the pigments 19'-butanoyloxyfucoxanthin (but-fuco, microgram per liter, indicative of brown tide) and zeaxanthin (microgram per liter, indicative of cyanobacteria). Significant increasing trends in zeaxanthin were observed in segments II and VII. Trends in butfuco were not significant for any segment population in the watershed and the general trend in increasing residential population may help to explain some of the increasing TN and TP (Fertig et al. 2013). There has been at least a doubling of the population since 1980 (Wazniak et al. 2007), and much, if not most, of this residential increase has not been sewered (Souza et al. 1993). Rigorously identifying and apportioning the sources of increasing nutrients to the Coastal Bays is going to remain a challenge for years to come. Anthropogenic inputs likely explain the increasing TN and TP (Fertig et al. 2013), but alone do not appear to explain the changes in nutrient forms nor the timing of those changes. An understanding of not only the total quantity of nutrient changes, but the quality of those changes, and why they may be occurring, is key to understanding how nutrient loads alter ecosystem function.

The relatively abrupt change in nutrient concentrations, and therefore Chl $a$ accumulations, could be due to several possibilities, as well as to positive reinforcing feedbacks among them. Here, we suggest that the effects of a combination of steadily increasing anthropogenic nutrient increases from development, superimposed on nutrient loads from farming and animal operations, were accelerated by changes in freshwater flow and associated biogeochemical responses. Freshwater flow was above the long-term mean from 1996 to 1998, then there was a long-term drier period until late 2002, another long-term wet period until 2007, and another reversal
Fig. 13 As for Fig. 4 except for the pigments fucoxanthin (microgram per liter, indicative of diatoms) and peridinin (microgram per liter, indicative of peridinin-containing dinoflagellates). Significantly increasing trends in fucoxanthin were observed in segments II and VII
Fucoxanthin and peridinin

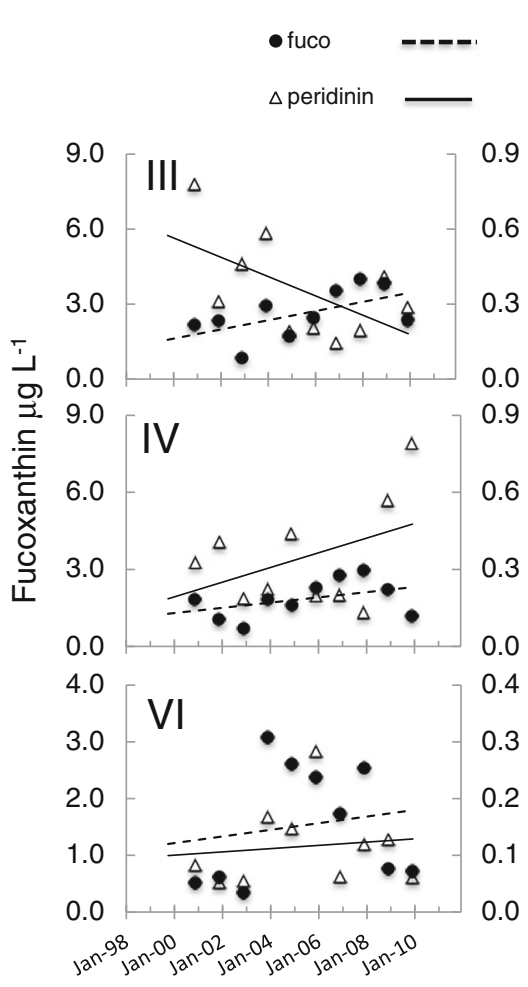

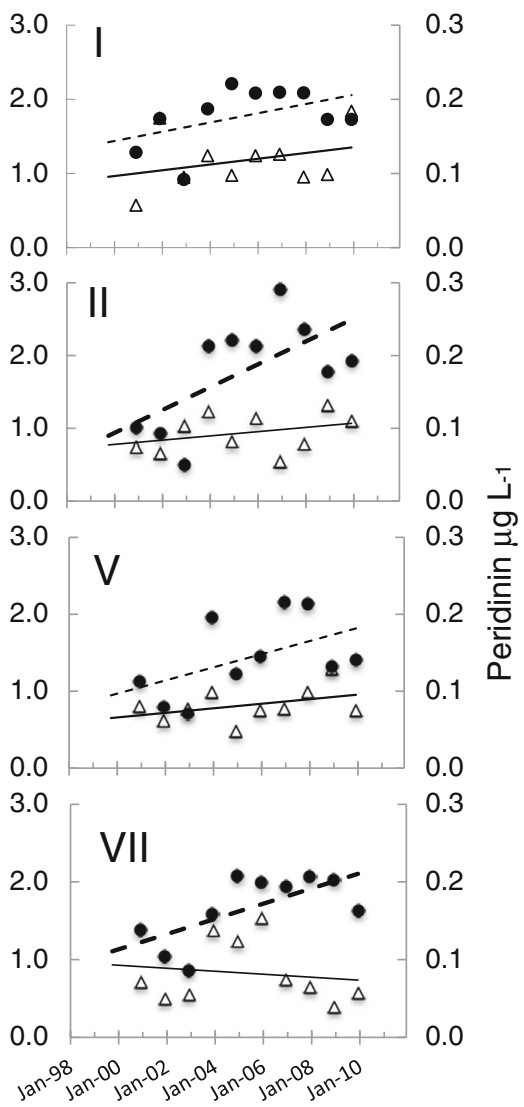




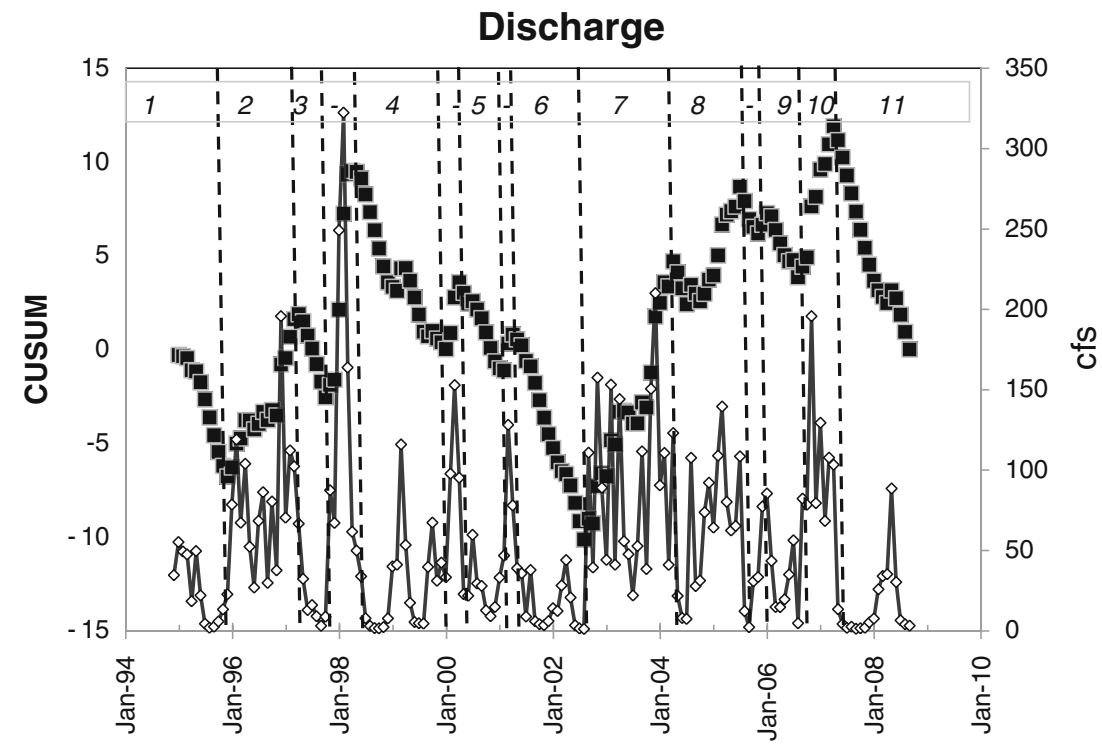

Fig. 14 Surface water monthly stream flow (cfs, open diamonds) and the cumulative sums of variability (CUSUM) for the same data (filled squares) for Nassawango Creek, near Snow Hill, MD, USA. Data were retrieved from USGS National Water Information System. Note that while this stream does not flow into the Coastal Bays, it is located

(Fig. 14). Regardless of whether anthropogenic nutrients were being delivered to the bays from surface runoff or from groundwater input, the extent of freshwater flow will affect nutrient loads. It has been estimated that low freshwater flow, as seen for example in the early 2000s, can result in increased terrestrial storage of nutrients, but these nutrients are subsequently transported to the bay when freshwater flow increases (e.g., Acker et al. 2005). The fate of such nutrient input from strong freshwater flows depends on many factors, and the long residence time of the Coastal Bays suggests that there is substantial biogeochemical processing of such nutrient. While the Coastal Bays do not receive significant riverine flows, they are not isolated from either direct or indirect effects of changes in flow.

Superimposed on the comparatively long dry period from 1998 to 2002 were a few episodic weather events, including hurricanes. Hurricanes have been associated with both algal blooms events and longer term changes in many other estuaries (Mallin and Corbett 2006; Paerl et al. 2006; Burkholder et al. 2006; Briceño and Boyer 2010). In June 2001, Tropical Storm Allison passed directly through these bays (http://www.nhc.noaa.gov/2001allison.html), bringing heavy rains and winds. The timing of the change in $\mathrm{PO}_{4}{ }^{3-}$ appeared to correspond with the passage of this storm as well as to other large unnamed weather events in fall 2001 and early 2002 which resulted in high water levels, overwash, and surface runoff especially in the northern segments. The change in $\mathrm{PO}_{4}{ }^{3-}$ following these storms may have resulted from freshwater flow directly, but there may also have been a significant release of $\mathrm{PO}_{4}{ }^{3-}$ from directly adjacent to them, and thus is representative of general groundwater flow patterns, not specific discharge. Vertical lines are drawn to indicate break points in the CUSUM trends. Numbers along the top of the graph indicate periods that are delineated by these break points. Periods shorter than a year were not given a number

benthic sources. Benthic resuspension events may be a significant source of nutrients to the water column in these shallow systems (Lawrence et al. 2004). Coincident pulses in $\mathrm{PO}_{4}{ }^{3-}$ with rain events have also been observed using continuous monitoring systems in the adjacent tributaries of Chesapeake Bay (Glibert et al. 2005b, 2008). Furthermore, it has been shown that different storm events can yield very different responses in nutrients even with the same storm intensity, depending on the frequency and timing of prior rain events and nutrient build-up in adjacent lands and sediments. Once P became elevated in the system, it tended to stay elevated on a long-term basis, even with seasonal variation. The passage of hurricanes similarly corresponded with changes in TP and $\mathrm{PO}_{4}{ }^{3-}$ in Florida Bay in 2005 (Briceño and Boyer 2010) and associated ecological changes in that system, including sustained picoplankton blooms (Glibert et al. 2009).

The change in $\mathrm{NH}_{4}{ }^{+}$appeared to be offset in time relative to that of $\mathrm{PO}_{4}{ }^{3-}$. A modest increase in $\mathrm{NH}_{4}{ }^{+}$was observed coincident with the increase in $\mathrm{PO}_{4}{ }^{3-}$ in 2001 (Figs. 5 and 8), but the major change in $\mathrm{NH}_{4}{ }^{+}$came a few years later, in 2003. This change appeared to be related to the long-term change from a dry to a wet period, but may have also been related to Tropical Storm Isabel that passed in September 2003. Resuspension of sediment due to wind may have contributed to elevated $\mathrm{NH}_{4}{ }^{+}$at this time. Yet, as was the case with $\mathrm{PO}_{4}{ }^{3-}$, once $\mathrm{NH}_{4}{ }^{+}$began to increase in the system, it remained elevated, on average, or increasing throughout all seasons and from year to year, further suggestive of biological and biogeochemical processing. Nutrients that 
had accumulated in the system were remobilized by the change in long-term dry to long-term wet conditions. The biogeochemical processes associated with this accelerated $\mathrm{NH}_{4}^{+}$accumulation are discussed in more detail below. First, however, potential changes in groundwater nutrient loads are considered.

Without major riverine sources of freshwater to these bays, nutrients largely enter the bays via groundwater, the delivery of which will vary with the strength of freshwater flow. Surface runoff is generally considered to be an insignificant nutrient source due to highly permeable sands and relatively low proportion of impermeable surfaces (Dillow and Greene 1999; Dillow et al. 2002), although storm events are exception to this generality. The groundwater table, calculated for the more southern regions of the coastal bays, is shallow, only a few meters below sea level (Galavotti 2004). During the wet period early in the time course, average concentrations of $\mathrm{NO}_{3}{ }^{-}$in the water column were higher than they were during the latter wet periods (Fig. 15c), although still comparatively low. However, the decrease in average concentrations during the latter wet periods for $\mathrm{NO}_{3}{ }^{-}$is more than offset by increases in $\mathrm{NH}_{4}{ }^{+}$during these wet periods (Fig. 15a). After 2002, higher average $\mathrm{NH}_{4}{ }^{+}$concentrations were apparent during wet years, but the change was even more dramatic for the dry periods (Fig. 15b).

If the change in long-term dry to long-term wet results in an increase in groundwater input, why would the increases in $\mathrm{NH}_{4}^{+}$exceed those of $\mathrm{NO}_{3}^{-}$? There may have been a change in nutrient composition of the groundwater. It is possible, perhaps, that management practices put into place years prior resulted in less $\mathrm{NO}_{3}{ }^{-}$in groundwater overall. $\mathrm{A}$ more likely possibility is a change in sediment biogeochemistry driven by increasing loads of N. Several changes in sediment biogeochemistry are hypothesized to have occurred in response to increased nutrient loads and freshwater flow; such changes would act synergistically with new loads to accelerate water quality decline. First, it is suggested that increased nutrient loads were directly or indirectly related to loss of SAV that, in turn, resulted in increased nutrient regeneration at the sediment-water interface (Fig. 11). The massive die-offs in SAV that were observed in 2005 were most likely a result of multiple stresses. Declines in transparency due to Chl $a$ accumulations could have contributed to their declines in growth due to light limitation. Summer 2005 also had exceptionally warm temperatures (E. Koch, personal communication). As $\mathrm{NH}_{4}{ }^{+}$accumulated, it too may
Fig. 15 Average concentrations (micromolar) of $\mathrm{NH}_{4}^{+}(\mathbf{a}, \mathbf{b})$, $\mathrm{NO}_{3}{ }^{-}(\mathbf{c}, \mathbf{d})$, and $\mathrm{PO}_{4}{ }^{3-}(\mathbf{e}, \mathbf{f})$ for all segments for wet and dry periods as defined in Fig. 14
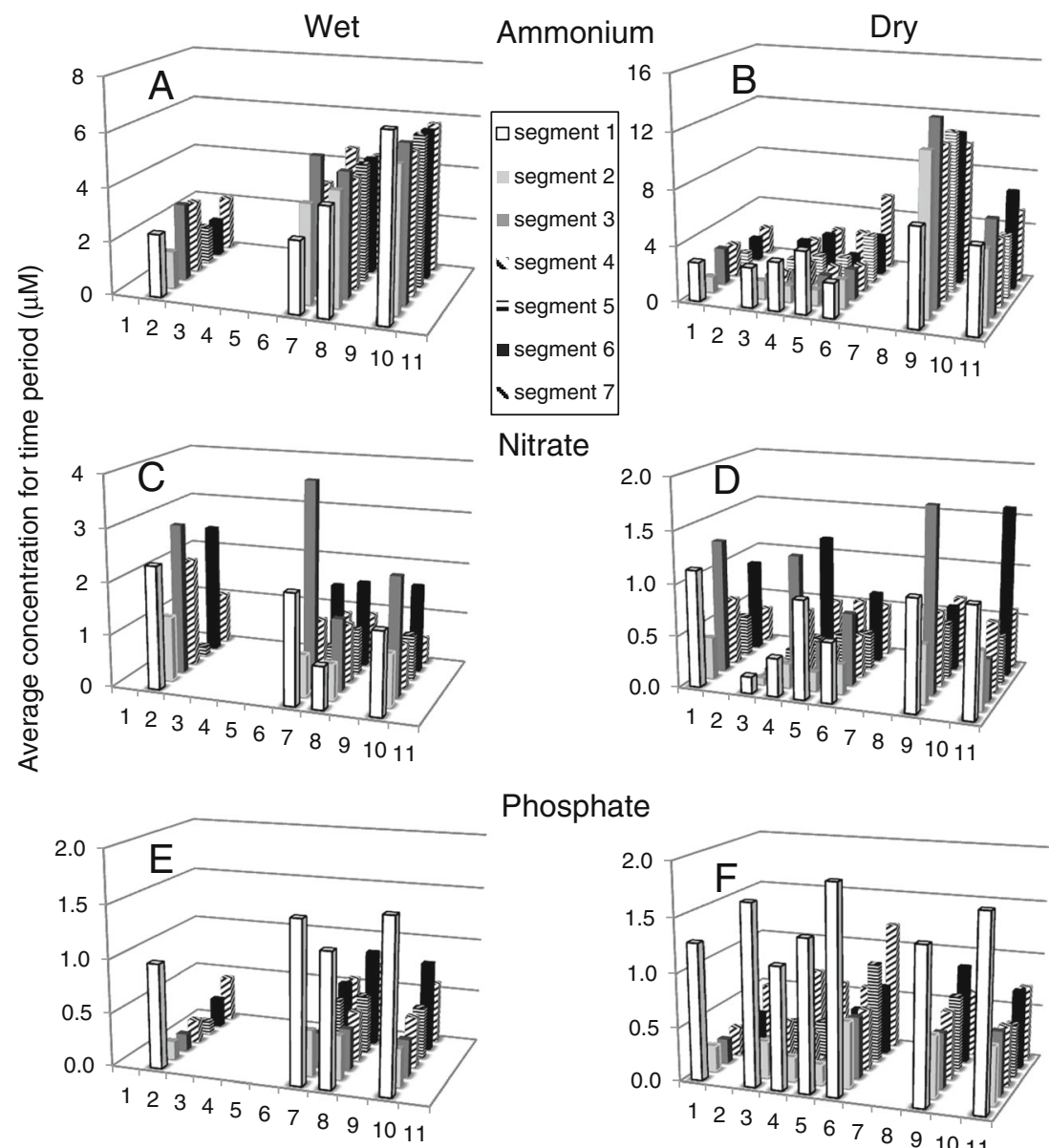

Phosphate

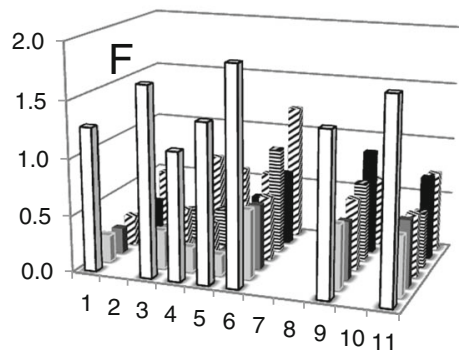

Time period 
have been deleterious to growth of these plants. In fact, previous studies have shown that water column $\mathrm{NH}_{4}{ }^{+}$levels of $25 \mu \mathrm{M}$ can cause seagrass death (Zimmerman et al. 1987; van Katwijk et al. 1997; Brun et al. 2002), and toxic effects can be prolonged in waters with poor residence times (Touchette and Burkholder 2001). In early summer 2005, at least in some regions, mean monthly concentrations exceeded $10 \mu \mathrm{M} \mathrm{NH}_{4}^{+}$, which suggests that there may have been days with considerably higher concentrations, even if such extreme levels were not prolonged. SAV die-offs would also contribute to organic matter that may have been regenerated in later months; some of the highest individual monthly measurements of $\mathrm{NH}_{4}^{+}$were observed in January 2006 (segment IV, $20.8 \mu \mathrm{M}$ ) and July 2006 (segment III, $38.6 \mu \mathrm{M})$. Since 2005, SAV have returned, but remain at levels less than those observed in 2002. This trend is, in fact, in contrast with that of the Virginia coastal bays where SAV have been increasing due to natural as well as anthropogenic actions to foster its proliferation (Orth et al. 2006, 2010; Orth and McGlathery 2012).

Another potential contributor to increasing $\mathrm{NH}_{4}{ }^{+}$is the adjacent degrading marshes. In many reaches of the Coastal Bays, marshes are eroding, leading to more sulfidic conditions (J. Cornwell, personal communication), which would, in turn, further support reducing environments leading to increasing $\mathrm{NH}_{4}^{+}$.

It is also suggested that microbially mediated dissimilatory $\mathrm{NO}_{3}{ }^{-}$reduction to $\mathrm{NH}_{4}{ }^{+}$(DNRA), a process by which $\mathrm{NO}_{3}{ }^{-}$ is converted to $\mathrm{NH}_{4}{ }^{+}$in the presence of organic matter under reducing conditions, may have become a more important process over time. DNRA is bioenergetically analogous to denitrification, being used for respiratory energy, except that the end product is $\mathrm{NH}_{4}{ }^{+}$instead of $\mathrm{N}_{2}$ gas. The DNRA process is stimulated in sediments with high organic matter and low oxygen concentrations (Tiedje 1988; An and Gardner 2002; Burgin and Hamilton 2007), both of which became established in the Coastal Bays with the more frequent development of algal blooms and organic enrichment. For such a process to have become dominant would require that the sediment interface had become a reducing environment, and thus, the $\mathrm{NO}_{3}{ }^{-}$, rather than effluxing to the water and increasing its concentration therein, would result in the reduction of $\mathrm{NO}_{3}{ }^{-}$to $\mathrm{NH}_{4}{ }^{+}$and an increase in its concentration. Thus, groundwater fluxes of $\mathrm{NO}_{3}{ }^{-}$have likely increased, but concentrations have not accumulated because of rapid biogeochemical processing. The potential importance of DNRA in Coastal Bays is large, although it has not been measured in these systems and should be pursued in future studies. In a wide range of marine and estuarine sediments, DNRA has been found to account for up to $70-100 \%$ of $\mathrm{NO}_{3}{ }^{-}$removal (Burgin and Hamilton 2007). If the source of the increasing $\mathrm{NH}_{4}{ }^{+}$is DNRA, then the ultimate source of the $\mathrm{N}$ is $\mathrm{NO}_{3}{ }^{-}$in groundwater, which represents new $\mathrm{N}$ loadings to the system, in addition to regeneration of decomposing organic matter from recent algal deposition and SAV die-backs.

While sustained hypoxia or anoxia is not common in these coastal lagoons due to their shallow and well-mixed nature, localized hypoxia does occur, especially on diel bases, especially during the period of algal blooms in summer (Wazniak et al. 2007, www.eyesonthebay.net). Localized hypoxia would not only provide an environmental condition conducive for DNRA but may also be inhibiting removal of $\mathrm{NO}_{3}{ }^{-}$by denitrification (Childs et al. 2002; Burgin and Hamilton 2007).

\section{Phytoplankton Community Composition Changes}

Lagoonal systems diverge along the classic lines delineated for herbivorous food web versus microbial food web systems (e.g., Legendre and Rassoulzadegan 1995). Where the algal community is dominated by cyanobacteria, or other picoplankton, the system generally sustains a proportionately greater flow through the microbial loop (Azam et al. 1983; Legendre and LeFevre 1995; Legendre and Rassoulzadegan 1995). The dominance of regenerated forms of N, and high organic loads, derived from both microzooplankton grazing and/or benthic fluxes, favors small-sized phytoplankton with high growth rates (Glibert 1998).

Although the Coastal Bays have had significant picoplankton assemblages for many years, the change in phytoplankton composition from the previously observed trend of increasing brown tide blooms to mixed communities with more cyanobacteria in some regions is also interesting. With nutrient change, the phytoplankton community of these bays underwent composition changes with time. Brown tide had previously been shown to increase from the early 1990s to the early 2000s (Trice et al. 2004; Glibert et al. 2007). Over the period of 1999-2004 inclusive, summer brown tide bloom strength increased with increasing $\mathrm{N}$, primarily as DON (Glibert et al. 2007). In recent years, brown tide has not continued to increase, but it has also not substantially decreased either. Elevated $\mathrm{NH}_{4}{ }^{+}$has been found to be inhibitory of rapid brown tide growth in the laboratory (P. Glibert, unpublished data). Inhibitory effects of $\mathrm{NH}_{4}{ }^{+}$on phytoplankton metabolism and growth have been observed in a wide range of systems, at concentrations as low as $1 \mu \mathrm{M}$, but such effects are manifested differently by different phytoplankton groups and at different concentration thresholds (e.g., Dortch 1980; Yoshima and Sharp 2006; Dugdale et al. 2007; Domingues et al. 2011). When the $\mathrm{NH}_{4}{ }^{+}$concentrations in the water began to be sustained at significantly higher concentrations than in prior years, beginning 2003, cyanobacterial picoplankton increased relative to brown tide. It should again be underscored that in contrast to the Trice et al. (2004) or Glibert et al. (2007) analyses, the data presented here are more regionally encompassing, and thus, it is likely 
that localized areas may have had increases (or decreases) that were not captured in the regional trends.

\section{Synthesis}

As previously reviewed (Glibert et al. 2010), blooms in lagoons are "poised on the edge" in several ways. First, they compete with other primary producers in the system, mainly benthic microphytobenthos, macroalgae, and SAV. Also, due to their small size, they do not have the physiology to store large pools of nutrients internally, so nutrient limitation is a continual challenge (e.g., Sunda et al. 2006). Blooms in lagoons may be responsible for significant ecosystem disruption, even at Chl $a$ levels that would not normally be taken as "bloom" conditions in a riverine-dominated estuarine system (Glibert et al. 2010). The average inorganic nutrient ratios for these bays, consistently below the Redfield proportion, would suggest some degree of $\mathrm{N}$ limitation, but this appears to be countered by the elevated TN/TP ratios, suggestive of a significant pool of DON. Those organisms that can thrive on reduced $\mathrm{N}$ do well under such conditions. Brown tide did well in the earlier decade because this reduced $\mathrm{N}$ was largely in the form of DON, but has apparently been succeeded in some regions by picocyanobacteria that not only do disproportionately well under reduced $\mathrm{N}$ conditions, but can also sustain elevated $\mathrm{NH}_{4}{ }^{+}$ concentrations. Regardless, in order for blooms of brown tide or picoplankton cyanobacteria to be sustained, nutrients must be supplied or regenerated on a continual basis, and it appears that this is indeed the case, and biogeochemical processes such as sediment organic matter remineralization and DNRA may be important in this regard, driven by increasing fluxes of groundwater $\mathrm{NO}_{3}{ }^{-}$that compound other anthropogenic nutrient loads. As EDAB species, these bloom-formers are often unpalatable or toxic and thereby reduce grazing, and the positive feedbacks of reduced grazing and/or bottom shading further contribute to the availability of nutrients for these blooms (Sunda et al. 2006).

In summary, there have been significant changes in the nutrient and plankton composition of the Coastal Bays over the past decade and half (Fig. 16). There appear to have been one or more episodic events that resulted in altered nutrient loads and sediment processing, but the major change occurred in 2001-2003 with a shift from a long-term dry to a long-term wet period. These changes, while apparent in the long-term data, were readily discernable using CUSUM analysis. It appears that increased nutrient anthropogenic loads, in conjunction with altered biogeochemical processes in this highly retentive system, have led to a maintenance condition of significantly higher ambient concentrations of both $\mathrm{N}$ and $\mathrm{P}$ than in prior decades. Virtually, all of the $\mathrm{N}$ in the water column is now in the chemically reduced form, $\mathrm{NH}_{4}{ }^{+}$or DON, resulting in phytoplankton community shifts to those species that can do well under such conditions.

The management problems of rapidly changing ecosystems such as this are very large. With long residence times, nutrients tend to stay in the system. Negative reinforcing biogeochemical feedbacks appear to have contributed to the deterioration of water quality and have accelerated the effects of anthropogenic nutrient loads. Nutrient reduction strategies for a region where nutrients are dominated by nonpoint sources including groundwater inputs are far more difficult than for regions where discrete point sources are readily identifiable. Further analysis of localized nutrient trends will aid in identifying local inputs and drivers of change. Further efforts to couple land use changes with nutrient loading patterns are needed. The responsiveness of the primary producers to change gives hope that with directed efforts a healthy system can again be established, even if such change may take many years. As noted by Kemp et al. (2005), in the analysis of eutrophication of the Chesapeake Bay, just as reinforcing feedbacks may accelerate ecosystem degradation
Fig. 16 Summary of the major changes in the Coastal Bays from 1994 to 2009. The curves in the upper panel represent z-CUSUM of freshwater discharge (gray diamonds), $\mathrm{NH}_{4}^{+}$(crosses), and $\mathrm{PO}_{4}{ }^{3-}$ (circles) of segment IV to illustrate the overall patterns. The major changes and the hypothesized reinforcing biogeochemical processes that occurred along the time course are summarized in the lower panel boxes

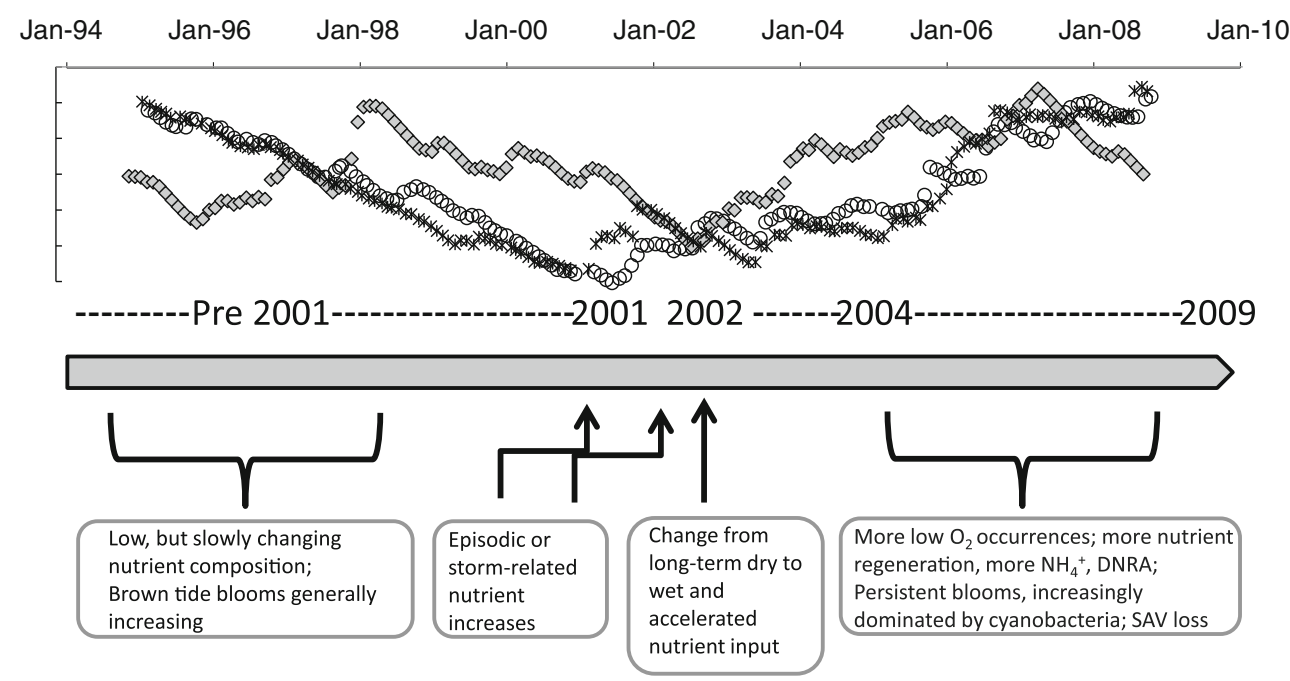


and eutrophication, positive biogeochemical reinforcing feedbacks can also help to reinforce restoration once water quality improvements begin to take hold. The Maryland Coastal Bays Program has numerous nutrient management policies in place. With increased intensity for dual nutrient reduction, long-term recovery of this system should be possible, or at least further degradation should be able to be slowed.

Acknowledgments This work was supported by the Maryland Coastal Bays Program. PMG was also supported by Maryland Sea Grant and the State and Federal Contractors Water Agency. The assistance of the Horn Point Analytical Services Laboratory is greatly appreciated. We thank C. Wazniak, W. Dennison, J. Cornwell, and C. McCollough for helpful discussions. This is contribution number 4633 from the University of Maryland Center for Environmental Sciences.

Open Access This article is distributed under the terms of the Creative Commons Attribution License which permits any use, distribution, and reproduction in any medium, provided the original author(s) and the source are credited.

\section{References}

Acker, J.C., L.W. Harding, G. Leptoukh, T. Zhu, and S. Shen. 2005. Remotely-sensed chl a at the Chesapeake Bay mouth is correlated with annual freshwater flow to Chesapeake Bay. Geophysical Research Letters 32: L05601. doi:10.1029/2004GL021852.

An, S., and W.S. Gardner. 2002. Dissimilatory nitrate reduction to ammonium (DNRA) as a nitrogen link, versus denitrification as a sink in a shallow estuary (Laguna Madre/Baffin Bay, Texas). Marine Ecology Progress Series 237: 41-50.

Andersen, R.A., R.R. Bidigare, M.D. Keller, and M. Latasa. 1996. A comparison of HPLC pigment signatures and election microscopic observations for oligotrophic waters of the North Atlantic and Pacific Oceans. Deep Sea Research 43: 517-537.

Ansotegui, A., J.M. Trigueros, and E. Orive. 2001. The use of pigment signatures to assess phytoplankton assemblage structure in estuarine waters. Estuarine, Coastal and Shelf Science 52: 689-703

Azam, F., T. Fenchel, J.G. Field, J.S. Gray, L.A. Meyer-Reil, and F. Thingstad. 1983. The ecological role of water-column microbes in the sea. Marine Ecology Progress Series 10: 257-263.

Bachmann, R.W., M.V. Hoyer, and D.E. Canfield Jr. 1999. The restoration of Lake Apopka in relation to alternative stable states. Hydrobiologia 394: 219-232.

Beckert, K.A., T.R. Fisher, J.M. O’Neil, and R.V. Jesien. 2011. Characterization and comparison of stream nutrients, land use, and loading patterns in Maryland Coastal Bay watersheds. Water, Air, and Soil Pollution 221: 255-273.

Berg, G.M., P.M. Glibert, M.W. Lomas, and M.A. Burford. 1997. Organic nitrogen uptake and growth by the chrysophyte Aureococcus anophagefferens during a brown tide event. Marine Biology 129: 377-387.

Boyer, J.N., S.K. Dailey, P.J. Gibson, M.T. Rogers, and D. MirGonzalez. 2006. The role of dissolved organic matter bioavailability in promoting phytoplankton blooms in Florida Bay. Hydrobiologia 561: 71-85.

Boyer, J.N., J.W. Fourqurean, and R.D. Jones. 1999. Seasonal and long-term trends in the water quality of Florida Bay (19891997). Estuaries 22(2B): 417-430.
Boynton, W.R., J.D. Hagy, L. Murray, C. Stokes, and W.M. Kemp. 1996. A comparative analysis of eutrophication patterns in a temperate coastal lagoon. Estuaries 19: 408-421.

Briceño, H.O., and J.N. Boyer. 2010. Climatic controls on phytoplankton biomass in a sub-tropical estuary, Florida Bay, USA. Estuaries and Coasts 33: 541-553.

Bronk, D.A., M.W. Lomas, P.M. Glibert, K.J. Shukert, and M.P. Sanderson. 2000. Total dissolved nitrogen analysis: comparisons between the persulfate, UV and high temperature oxidation methods. Marine Chemistry 69: 163-178.

Brun, F.G., I. Hernandez, J.J. Vergara, G. Peralta, and J.L. PerezLlorens. 2002. Assessing the toxicity of ammonium pulses to the survival and growth of Zostera noltii. Marine Ecology Progress Series 225: 177-187.

Burgin, A., and S.K. Hamilton. 2007. Have we overemphasized the role of denitrification in aquatic ecosystems? A review of nitrate removal pathways. Frontiers in Ecology 5: 89-96.

Burkholder, J.M., D.A. Dickey, C. Kinder, R.E. Reed, M.A. Mallin, G. Melia, M.R. McIver, L.B. Cahoon, C. Brownie, N. Deamer, J. Springer, H. Glasgow Jr., D. Toms, and J. Smith. 2006. Comprehensive trend analysis of nutrients and related variables in a large eutrophic estuary: a decadal study of anthropogenic and climatic influences. Limnology and Oceanography 51: 463-487.

Childs, C.R., N.R. Rabalais, R.E. Turner, and L.M. Proctor. 2002. Sediment denitrification in the Gulf of Mexico zone of hypoxia. Marine Ecology Progress Series 240: 285-290.

Christian, R.R., J.N. Boyer, and D.W. Stanley. 1991. Multi-year distribution patterns of nutrients within the Neuse River Estuary, North Carolina. Marine Ecology Progress Series 71: 259-274.

Dillow, J.J.A., W.S.L. Banks, and M.J. Smigaj. 2002. Ground-water quality and discharge to Chincoteague and Sinepuxent bays adjacent to Assateague Island National Seashore, Maryland: U.S. Geological Survey Water-Resources Investigation 02-4029. Baltimore: USGS.

Dillow, J. J. A., and E. A. Greene. 1999. Ground-water discharge and nitrate loadings to the coastal bays of Maryland: U.S. Geological Survey Water-Resources Investigations Report 99-4167.

Domingues, R.B., A.B. Barbossa, U. Sommer, and H.M. Galvao. 2011. Ammonium, nitrate and phytoplankton interactions in a freshwater tidal estuarine zone: potential effects of cultural eutrophication. Aquatic Science 73: 331-343.

Dortch, Q. 1980. The interaction between ammonium and nitrate uptake in phytoplankton. Marine Ecology Progress Series 61: 183-201.

Dugdale, R.C., F.P. Wilkerson, V.E. Hogue, and A. Marchi. 2007. The role of ammonium and nitrate in spring bloom development in San Francisco Bay. Estuarine, Coastal and Shelf Science 73: 17-29.

Fertig, B., J.M. O'Neil, K.A. Beckert, C.J. Cain, D.M. Needham, T.J.B. Carruthers, and W.C. Dennison. 2013. Elucidating terrestrial nutrient sources to a coastal lagoon, Chincoteague Bay, Maryland USA. Estuarine, Coastal and Shelf Science 116: 1-10.

Galavotti, H. S. 2004. Spatial profiles of sediment denitrification at the ground water-surface water interface in Cobb Mill Creek on the eastern shore of Virginia. PhD Thesis, University of Virginia, Charlottesville, VA. 100 pp.

Glibert, P.M. 1998. Interactions of top-down and bottom-up control in planktonic nitrogen cycling. Hydrobiologia 363: 1-12.

Glibert, P.M., J. Boyer, C. Heil, C. Madden, B. Sturgis, and C. Wazniak. 2010. Blooms in Lagoons: different from those of river-dominated estuaries. In Coastal lagoons: critical habitats of environmental change, ed. M. Kennish and H. Paerl, 91-114. Boca Raton: Taylor and Francis.

Glibert, P.M., C.A. Heil, and C.J. Madden. 2009. Florida Bay: a subtropical system increasingly influenced by multiple stressors. Contributions in Marine Science 38: 1-4.

Glibert, P.M., V. Kelly, L.A. Codispoti, W.C. Boicourt, T.M. Trice, and B. Michael. 2008. In situ nutrient monitoring: a tool for capturing 
nutrient variability and the antecedent conditions that support algal blooms. Harmful Algae 8: 175-181.

Glibert, P.M.S. Seitzinger, C.A. Heil, J.M. Burkholder, M.W. Parrow, L.A. Codispoti, and V. Kelly. 2005a. The role of eutrophication in the global proliferation of harmful algal blooms: new perspectives and new approaches. Oceanography 18(2): 198-209.

Glibert, P.M., T.M. Trice, B. Michael, and L. Lane. 2005b. Urea in the tributaries of the Chespeake and Coastal Bays of Maryland. Water, Air, and Soil Pollution 160: 229-243.

Glibert, P.M., C.E. Wazniak, M. Hall, and B. Sturgis. 2007. Seasonal and interannual trends in nitrogen and brown tide in Maryland's Coastal Bays. Ecological Applications 17: S79-S87.

Gobler, C.J., D.J. Lonsdale, and G.L. Boyer. 2005. A review of the causes, effects, and potential management of harmful algal blooms caused by Aureococcus anophagefferens (Hargraves et Sieburth). Estuaries 28: 726-749.

Goshorn, D., J. Deeds, P. Tango, C. Poukish, A. Place, M. McGinty, W. Butler, C. Luckett, and R. Magnien. 2004. Occurrences of Karlodinium micrum and its association with fish kills in Maryland estuaries. In Harmful algae 2002: Proceedings of the Tenth International Conference of Harmful Algal Blooms, ed. K.A. Steidinger, J.H. Landsberg, C.A. Tomas, and G.A. Vargo, 361-363. FL: St. Petersburg.

Jeffrey, S.W., and M. Vesk. 1997. Introduction to marine phytoplankton and their pigment signatures. In Phytoplankton pigments in oceanography: guidelines to modern methods, ed. S.W. Jeffrey, R.F.C. Mantoura, and S.W. Wright, 37-85. Paris: UNESCO.

Kana, T.M., P.M. Glibert, R. Goericke, and N. Welschmeyer. 1988. Zeaxanthin and B-carotene in Synechococcus WH7803 respond differently to irradiance. Limnology and Oceanography 33: 16231627.

Keefe, C.W., K.L. Blodniker, W.R. Boynton, C.A. Clark, J.M. Frank, N.L. Kaumeyer, M.W. Weir, K.V. Wood and C.F. Zimmermann. 2004. Nutrient analytical services laboratory standard operating procedures. Technical Report Number SS-80-04-CBL. Chesapeake Biological Laboratory, University of Maryland Center for Environmental Science, Cambridge, MD, USA.

Kemp, W.M., W.R. Boynton, J.E. Adolf, D.F. Boesch, W.C. Boicourt, G. Brush, J.C. Cornwell, T.R. Fisher, P.M. Glibert, J.D. Hagy, L.W. Harding, E.D. Houde, D.G. Kimmel, W.D. Miller, R.I.E. Newell, M.R. Roman, E.M. Smith, and J.C. Stevenson. 2005. Eutrophication in Chesapeake Bay: historical trends and ecological interactions. Marine Ecology Progress Series 303: 1-29.

Kurtz, J.C., N. Detenbeck, V.D. Engle, K. Ho, L.M. Smith, S.J. Jordan, and D. Campbell. 2006. Classifying coastal waters: current necessity and historical perspective. Estuaries and Coasts 29: 107123

Lane, L., S. Rhoades, C. Thomas, and L. Van Heukelem. 2000. Analytical services laboratory-standard operating procedures. Technical Report Number TS-264-00. Horn Point Laboratory, University of Maryland Center for Environmental Science, Cambridge MD, USA.

LaRoche, J., R. Nuzzi, R. Waters, K. Wyman, P.G. Falkowski, and D.W.R. Wallace. 1997. Brown tide blooms in Long Island's coastal waters linked to variability in groundwater flow. Global Change Biology 3: 397-410.

Lawrence, D., M.J. Dagg, H. Liu, S.R. Cummings, P.B. Ortner, and C. Keble. 2004. Wind events and benthic-pelagic coupling in a shallow subtropical bay in Florida. Marine Ecology Progress Series 266: 1-13.

Legendre, L., and J. Lefevre. 1995. Microbial food webs and the export of biogenic carbon in oceans. Aquatic. Microbial Ecology 9: 69-77.

Legendre, L., and F. Rassoulzadegan. 1995. Plankton and nutrient dynamics in marine waters. Ophelia 14: 153-172.

Lomas, M.W., P.M. Glibert, D.A. Clougherty, D.E. Huber, J. Jones, J. Alexander, and E. Haramoto. 2001. Elevated organic nutrient ratios associated with brown tide blooms of Aureococcus anophagefferens (Pelagophyceae). Journal of Plankton Research 23: 1339-1344.

Lomas, M.W., T.M. Kana, H.L. MacIntyre, J.C. Cornwell, R. Nuzzi, and R. Waters. 2004. Interannual variability of Aureococcus anophagefferens in Quantuck Bay, Long Island: natural test of the DON hypothesis. Harmful Algae 3: 389-402.

MacNally, R., and B.T. Hart. 1997. Use of CUSUM methods for waterquality monitoring in storages. Environmental Science and Technology 31: 2114-2119.

Madden, C. 2010. Florida Bay. In: P.M. Glibert, C.J. Madden, W. Boynton, D. Flemer, C. Heil and J. Sharp, eds. Nutrients in estuaries: a summary report of the National Estuarine Experts Workgroup 2005-2007. EPA Office of Water.

Mallin, M.A., and C.A. Corbett. 2006. How hurricane attributes determine the extent of environmental effects: multiple hurricanes and different coastal systems. Estuaries and Coasts 29: 1046-1061.

Manly, B.F.J., and D.I. Mackenzie. 2003. CUSUM environmental monitoring in time and space. Environmental and Ecological Statistics 10: 231-247.

Maryland Coastal Bays Program (MCBP). 1999. Todays treasures for tomorrow: towards a brighter future. A Comprehensive Conservation Management Plan for Maryland's Coastal Bays. Annapolis, Maryland, USA: Maryland Department of Natural Resources.

Mesnil, B., and P. Petitgas. 2009. Detection of changes in time series using CUSUM control charts. Aquatic Living Resources 22: 187-192.

Orth, R.J., M.L. Luckenbach, S.R. Marion, K.A. Moore, and D.J. Wilcox. 2006. Seagrass recovery in the Delmarva coastal bays, USA. Aquatic Botany 84: 26-36.

Orth, R.J., S.R. Marion, K.A. Moore, and D.J. Wilcox. 2010. Eelgrass (Zostera marina L.) In the Chesapeake Bay region of midAtlantic coast of the USA: challenges in conservation and restoration. Estuaries and Coasts 33: 139-150.

Orth, R.J., and K.J. McGlathery. 2012. Eelgrass recovery in the coastal bays of the Virginia coastal reserve, USA. Marine Ecology Progress Series 448: 173-176.

Paerl, H., L.M. Valdes, B.L. Peierls, J.E. Adolf, and L.W. Harding. 2006. Anthropogenic and climatic influences on the eutrophication of large estuarine systems. Limnology and Oceanography 51: 448-462.

Page, E.S. 1954. Continuous inspection schemes. Biometrika 41: 100 115.

Poor, N.D. 2010. Effect of lake management efforts on the trophic state of a subtropical shallow lake in Lakeland, Florida, USA. Water, Air, and Soil Pollution 207: 333-347.

Pritchard, D.W. 1969. Salt balance and exchange rate for Chincoteague Bay. Chesapeake Science 1: 48-57.

Scheffer, M., and S.R. Carpenter. 2003. Catastrophic regime shifts in ecosystems: linking theory to observation. Trends in Ecology \& Evolution 18: 648-656.

Scheffer, M., H. Hosper, M.-L. Meijer, B. Moss, and E. Jeppesen. 1993. Alternative equilibria in shallow lakes. Trends in Ecology \& Evolution 8: 260-262.

Scheffer, M., S. Szabo, A. Gragnani, E.H. van Nes, S. Rinaldi, N. Kautsky, J. Norberg, R.M.M. Roijackers, and R.J.M. Franken. 2003. Floating plant dominance as a stable state. Proceedings of the National Academy of Sciences of the United States of America 100: 4040-4045.

Solórzano, L., and J.H. Sharp. 1980. Determination of total dissolved phosphorus and particulate phosphorus in natural waters. Limnology and Oceangraphy 25: 752-754.

Souza, S., B. Krinsky, and J. Seibel. 1993. Marylandś Coastal Bays: an assessment of aquatic ecosystems, pollutant loadings, and management options. Baltimore MD: Maryland Department of the Environment. 
Sunda, W.G., E. Granéli, and C.J. Gobler. 2006. Positive feedback and the development and persistence of ecosystem disruptive algal blooms. Journal of Phycology 42: 963-974.

Suzuki, K., N. Handa, H. Kiyosawa, and J. Ishizaka. 1997. Temporal and spatial distribution of phytoplankton pigments in the central Pacific Ocean along $175^{\circ} \mathrm{E}$ during the boreal summers of 1992 and 1993. Journal of Oceanography 53: 383-396.

Tátrai, I., G. Boros, Á.I. György, K. Mátyás, J. Korponai, P. Pomogyi, M. Havasi, and T. Kucserka. 2009. Abrupt shift from clear to turbid state in a shallow eutrophic, biomanipulated lake. Hydrobiologia 620: 149-161.

Tiedje, J.M. 1988. Ecology of denitrification and dissimilatory nitrate reduction to ammonium. In Biology of anaerobic microorganisms, ed. A.J.B. Zehnder. New York: Wiley.

Touchette, B.W., and J. Burkholder. 2001. Nitrate reductase activity in a submersed marine angiosperm: controlling influences of environmental and physiological factors. Plant Physiology and Biochemistry 39: 583-593.

Trice, T.M., P.M. Glibert, C. Lea, and L. Van Heukelem. 2004. HPLC pigment records provide evidence of past blooms of Aureococcus anophagefferens in the Coastal Bays of Maryland and Virginia, USA. Harmful Algae 3: 295-304.

United States Department of Agriculture (USDA). 2007. Census of agriculture. http://www.agcensus.usda.gov/Publications/2007/ index.php. Accessed 22 Aug 2012.
Valderrama, J.C. 1981. The simultaneous analysis of total nitrogen and total phosphorus in natural waters. Marine Chemistry 10: 109122.

Van Heukelem, L., and C.S. Thomas. 2001. Computer-assisted highperformance liquid chromatography method development with applications to the isolation and analysis of phytoplankton pigments. Journal of the Chromatography Association 910: 31-49.

van Katwijk, M.M., L.H.T. Vergeer, G.H.W. Schmitz, and J.G.M. Roelofs. 1997. Ammonium toxicity in eelgrass Zostera marina. Marine Ecology Progress Series 157: 159-173.

Wazniak, C.E., and P.M. Glibert. 2004. Potential impacts of brown tide, Aureococcus anophagefferens, on juvenile hard clams, Mercenaria mercenaria, in the Coastal Bays of Maryland, USA. Harmful Algae 3: 321-329.

Wazniak, C.E., M.R. Hall, T. Carruthers, and R. Sturgis. 2007. Linking water quality to living resources in a mid-Atlantic lagoon system, USA. Ecological Applications 17(5): S64-S78.

Yoshima, K., and J.H. Sharp. 2006. Phytoplankton response to nutrient enrichment in an urbanized estuary: apparent inhibition of primary productivity by overeutrophication. Limnology and Oceanography 51: 424-434.

Zimmerman, R.C., R.D. Smith, and R.S. Alberte. 1987. Is growth of eelgrass nitrogen limited? A numerical simulation of the effects of light and nitrogen on the growth dynamics of Zostera marina. Marine Ecology Progress Series 41: 167-176. 